\title{
ORNL ISOTOPIC POWER FUELS QUARTERLY REPORT FOR PERIOD ENDING DECEMBER 31, 1973
}

\author{
Eugene Lamb
}

\section{OAK RIDGE NATIONAL LABORATORY}

OPERATED BY UNION CARBIDE CORPORATION - FOR THE U.S. ATOMIC ENERGY COMMISSION 


\section{DISCLAIMER}

This report was prepared as an account of work sponsored by an agency of the United States Government. Neither the United States Government nor any agency Thereof, nor any of their employees, makes any warranty, express or implied, or assumes any legal liability or responsibility for the accuracy, completeness, or usefulness of any information, apparatus, product, or process disclosed, or represents that its use would not infringe privately owned rights. Reference herein to any specific commercial product, process, or service by trade name, trademark, manufacturer, or otherwise does not necessarily constitute or imply its endorsement, recommendation, or favoring by the United States Government or any agency thereof. The views and opinions of authors expressed herein do not necessarily state or reflect those of the United States Government or any agency thereof. 


\section{DISCLAIMER}

Portions of this document may be illegible in electronic image products. Images are produced from the best available original document. 
Printed in the United States of America. Available from

National Technical Information Service

U.S. Department of Commerce

5285 Port Royal Road, Springfield, Virginia 22151

Price: Printed Copy $\$ 4.00$; Microfiche $\$ 0.95$

This report was prepared as an account of work sponsored by the United States Government. Neither the United States nor the United States Atomic Energy Commission, nor any of their employees, nor any of their contractors, subcontractors, or their employees, makes any warranty, express or implied, or assumes any legal liability or responsibility for the accuracy, completeness or usefulness of any information, apparatus, product or process disclosed, or represents that its use would not infringe privately owned rights. 
ORNL -4939

UC-33 - Nuclear Propulsion

Systems and Aerospace Safety

Contract No. W-7405-eng-26

ISOTOPES DEVELOPMENT CENTER

ORNL ISOTOPIC POWER FUELS QUARTERLY REPORT FOR PERIOD ENDING DECEMBER 31, 1973

Eugene Lamb

Isotopes Division

FEBRUARY 1974

This report was prepared as account of work sponsored by the United States Government. Neither the United States nor the United States Atomic Energy Commission, nor any of their employees, nor any of their contractors, subcontractors, or ther employees, makes any warranty, express or impled, or assumes any legal lability or responsibility for the accuracy, comlegal lability or responsibility for the accuracy, com-
pleteness or usefulness of any information, apparatus, product or process disclosed, or represents that tts use would not infringe privately owned rights.

\footnotetext{
OAK RIDGE NATIONAL LABORATORY

Oak Ridge, Tennessee 37830

operated by

UNION CARBIDE CORPORATION

for the

U.S. ATOMIC ENERGY COMMISSION
} 
SUMMARY ....................... 1

CURIUM-244 FUEL DEVELOPMENT . . . . . . . . . . . . . 2

${ }^{244} \mathrm{Cm}_{2} \mathrm{O}_{3}$ Compatibility Program .............. 2

Compatibility Couple Tests . . . . . . . . . . 2

FY 1974 Compatibility Matrix . . . . . . . . . 5

Compatibility With Ceramic Materials . . . . . . . . 7

Free Energy Calculations $-\mathrm{Cm}_{2} \mathrm{O}_{3}$ With

Haynes 188, $\mathrm{Ta}-10 \% \mathrm{~W}$, and $\mathrm{TZM}$........... 9

Effect of Oxygen Solubility in Container Alloys

on Interaction With Curium Oxide Heat Sources . . . . . . 14

Free Energy Calculations for the Reaction

of Beryllium With $\mathrm{Cm}_{2} \mathrm{O}_{3}$ Heat Source Product . . . . . . 16

Data Needed for Calculation of $\mathrm{Cm}_{2} \mathrm{O}_{3}$ Free Energy . . . . . 17

Summary of Thermodynamic Calculation . . . . . . . 18

${ }^{244} \mathrm{Cm}_{2} \mathrm{O}_{3}$ Property Characterization ............ 19

Helium Release . . . . . . . . . . . . 19

Vapor Pressure ................ 22

X-Ray Diffraction . . . . . . . . . . 24

Emissivity . . . . . . . . . . . . 26

Heat Capacity . . . . . . . . . . . 26

Dimensional Stability . . . . . . . . . . . 26

Behavior of Hot-Pressed $\mathrm{Cm}_{2} \mathrm{O}_{3}$ Pellet

in Boiling Distilled Water........... 27

${ }^{244} \mathrm{Cm}_{2} \mathrm{O}_{3}$ Radiation Measurements ......... 29

Curium From Power Reactor Fuels . . . . . . . . 29

Criticality of ${ }^{244} \mathrm{Cm}_{2} \mathrm{O}_{3}$ Fuels ........... 33

REFERENCES . . . . . . . . . . . . . . . . 33 
Fig. 1. Electron-Beam Scanning Images

of $\mathrm{Cm}_{2} \mathrm{O}_{3}$-Pt Compatibility Test ............4 4

Fig. 2. ${ }^{244} \mathrm{Cm}_{2} \mathrm{O}_{3}$ Mechanical Properties Compatibility Test System . . . . . . . . . 6

Fig. 3. Temperature Versus Time for Helium Release Tests . . . . 19

Fig. 4. Helium Release Rate Versus Time $(0-152 \mathrm{hr})$. . . . . . 19

Fig. 5. Helium Release Rates Versus Time $(0-900 \mathrm{hr})$. . . . . 21

Fig. 6. Comparison of Calculated and Measured Yield of ${ }^{244} \mathrm{Cm}$ in Enriched-Uranium-Fueled PWR ....... 30

\section{LIST OF TABLES}

Table 1. Status of Compatibility Tests . . . . . . . . . 3

Table 2. ${ }^{244} \mathrm{Cm}_{2} \mathrm{O}_{3} /$ Ceramic Compatibility Experiments . . . . . 7

Table 3. Partial Molar Free Energies of Mixing of the Constituents in Haynes 188 Alloy . . . . . . . . 9

Table 4. Gibbs Free Energy of Formation of Oxides Involved in Haynes 188/Curium Fuel Reactions . . . . . . . 10

Table 5. Free Energies of Reaction for Haynes 188/ $\mathrm{Cm}_{2} \mathrm{O}_{3}$ Reactions................ 11

Table 6. Free Energies of Reaction for Haynes $188 / \mathrm{PuO}_{2}$ Reactions . 11

Table 7. Partial Molar Free Energies of Mixing of Tungsten and Tantalum in Ta-10\% W Alloy . . . . . 12

Table 8. Gibbs Free Energy of Formation of Oxides Involved in Ta-10\% W/Curium Fuel Reactions . . . . 12

Table 9. Free Energies of Reaction for Ta-10\% W/Curium Fuel Reactions . . . . . . . . . . . . 12

Table 10. Partial Molar Free Energies of Mixing of Constituents in TZM . . . . . . . . . . . . 13

Table 11. Gibbs Free Energy of Formation of Oxides Involved in TZM/Curium Fuel Reactions ......... 13 
Table 12. Free Energies of Reaction for TZM/Curium

Fuel Reactions . . . . . . . . . . . . . 14

Table 13. Equilibrium Oxygen Partial Pressures Above $\mathrm{PuO}_{2}$ and Average Equilibrium Oxygen Pressure for $\mathrm{PuO}_{2}$

Decomposition to $\mathrm{Pu}_{2} \mathrm{O}_{3}$. . . . . . . . . . . 15

Table 14. Gibbs Free Energy as a Function of Temperature . . . . 17

Table 15. Disintegration of $\mathrm{Cm}_{2} \mathrm{O}_{3}$ Pellet

in Boiling Distilled Water . . . . . . . . . 28

Table 16. Isotopic Abundance of Curium

Recovered From Boiling Water Reactor Fuel . . . . . 29

Table 17. Influence of $235 \mathrm{U}$ Enrichment on Isotopic Abundance

of $244 \mathrm{Cm}$ at $33 \mathrm{GWD} / \mathrm{MTU}$ and Four-Year Decay Period . . . 31

Table 18. Influence of Burnup on Isotopic Abundance of ${ }^{244} \mathrm{Cm}$ at 3. 3\% $235 \mathrm{U}$ Reactor Fuel Enrichment and Four-Year

Decay Period . . . . . . . . . . . . . . 32

Table 19. Power Density of ${ }^{244} \mathrm{Cm}_{2} \mathrm{O}_{3}$ Fuel Forms . . . . . . . 32 
ORNL ISOTOPIC POWER FUELS QUARTERLY REPORT

FOR PERIOD ENDING DECEMBER 37, 1973

Eugene Lamb

\section{SUMMARY}

Heat soak periods were completed on the remaining 49 couples of the compatibility matrix which was put on test in May 1973. Examination of the 18 couples which were taken off test in August 1973 was completed. The planned short-term ceramic compatibility matrix exposures were completed, and optical microscope examinations were done. Experiments were started to develop fabrication techniques for preparation of an 11-couple compatibility matrix scheduled for FY 1974. The design of this matrix was finalized, and component procurement was started. Free energy calculations were made for the reactions of $\mathrm{Cm}_{2} \mathrm{O}_{3}$ fuel with Haynes $188, \mathrm{Ta}-10 \% \mathrm{~W}$, and TZM alloys and with beryllium.

Measurements of the helium release characteristics of hot-pressed $24{ }^{4} \mathrm{Cm}_{2} \mathrm{O}_{3}$ were started at 500,650 , and $800^{\circ} \mathrm{C}$. A vapor pressure determination was run on curium metal in the temperature range from 900 to $1800^{\circ} \mathrm{C}$. Vapor pressure measurements of ${ }^{244} \mathrm{Cm}_{2} \mathrm{O}_{3}$ in the range from 1200 to $1600^{\circ} \mathrm{C}$ were begun; these will continue next quarter. Examinations by $x$-ray diffraction were made on materials resulting from exposures of ${ }^{244} \mathrm{Cm}_{2} \mathrm{O}_{3}$ to flowing seawater, boiling seawater, and dry air as well as on ${ }^{24}{ }^{4} \mathrm{Cm}_{2} \mathrm{O}_{3}$ samples taken at various stages in the fuel forming process. The equipment which will be used for emissivity measurements was improved and checked with nonradioactive samples.

Observations of two $25-\mathrm{W}{ }^{244} \mathrm{Cm}_{2} \mathrm{O}_{3}$ pellets stored in argon and one $25-\mathrm{W} 2{ }^{24} \mathrm{Cm}_{2} \mathrm{O}_{3}$ pellet stored in dry air continued. A ${ }^{244} \mathrm{Cm}_{2} \mathrm{O}_{3}$ pellet was leached with boiling distilled water and the rate of ${ }^{244} \mathrm{Cm}$ loss measured. Calculational studies of $244 \mathrm{~cm}$ yields and isotopic abundances from various types of reactor operations were continued. A study of the potential for criticality problems in $244 \mathrm{Cm}$ assemblies was initiated. 


\title{
CURIUM-244 FUEL DEVELOPMENT
}

(Division of Space Nuclear Systems Program LR 3001033 )

\author{
${ }^{24} \mathrm{Cm}_{2} \mathrm{O}_{3}$ Compatibility Program
}

Compatibility Couple Tests (T. A. Butzer and J.R. Distefano)

The compatibility test matrix outlined in Table 1 has been completed, and examination of the couples exposed at $1100^{\circ} \mathrm{C}$ for $2500 \mathrm{hr}$ (sets 3, 4,5 , and 6) has also essentially been completed. Results of these tests can be summarized as follows:

Platinum - Reacted with $\mathrm{Cm}_{2} \mathrm{O}_{3}$. Microprobe analysis indicates that the reaction phase contains $272 \%$ platinum and $14 \%$ curium.

$\underline{\text { Pt-2608M }}$ - Surface roughening and grain boundary attack up to maximum of 1 to 2 mils. Oxygen pickup from 10 to $90 \mathrm{ppm}$.

Pt $t_{3}$ - Generally no attack. Isolated areas of grain boundary attack from 1 to $3 \mathrm{mils}$.

Iridium - Generally no attack. Attack to <I mil depth noted in one specimen.

Graphite - No attack.

Of the five materials tested only unalloyed platinum appears unsuitable for containing ${ }^{244} \mathrm{Cm}_{2} \mathrm{O}_{3}$ at $1100^{\circ} \mathrm{C}$. Test conditions included both helium and vacuum and under both conditions capsules were in contact with graphite or not. It was not apparent that these variables significantly affected the test results. The inner capsules were in contact with graphite in sets 3 and 6 but no reaction with the graphite was observed. Samples heat. treated under the test conditions, but in the absence of ${ }^{244} \mathrm{Cm}_{2} \mathrm{O}_{3}$ showed no unusual microstructural changes.

Unalloyed platinum reacted with $\mathrm{Cm}_{2} \mathrm{O}_{3}$ under all conditions after $2500 \mathrm{hr}$ at $1100^{\circ} \mathrm{C}$. Electron beam microprobe data from one of the tests is summarized in Fig. 1. The reaction product is the area labeled "b" in the upper left hand picture. It contains $72 \%$ platinum and $14 \%$ curium from $x$-ray intensity data. If these data are normalized to $100 \%$ (i.e., assume no other constituents were present), the values would be $84 \% \mathrm{Pt}-16 \% \mathrm{Cm}$. This corresponds stoichiometrically to a compound of the type $\mathrm{CmPt}_{5}$. In addition to the reaction product there was a darker gray phase around the outer edge of ${ }^{244} \mathrm{Cm}_{2} \mathrm{O}_{3}$ pellet as indicated by the backscattered electron picture in the lower left of Fig. 1. However, x-ray intensity data indicated it to contain the same curium concentration as the bulk pellet.

Sets $1,2,7,8,9$, and 10, shown in Table 1 , have now completed their exposures at 900 to $1400^{\circ} \mathrm{C}$. Examination of these materials is scheduled to begin in early February. 
Table 1. Status of Compatibility Tests

\begin{tabular}{rlccc}
\hline Set $^{a}$ & $\begin{array}{c}\text { Start } \\
\text { of Test }\end{array}$ & $\begin{array}{c}\text { Thermal } \\
\text { Cycles }\end{array}$ & $\begin{array}{c}\text { Cumulative } \\
\text { Hours }\end{array}$ & End of Test \\
\hline 1 & $5-3-73$ & 1 & 5021 & $12-3-73$ \\
2 & $5-3-73$ & 1 & 5021 & $12-3-73$ \\
3 & $4-16-73$ & 3 & 2560 & $8-6-73$ \\
4 & $4-16-73$ & 3 & 2560 & $8-6-73$ \\
5 & $4-17-73$ & 2 & 2510 & $8-9-73$ \\
6 & $4-17-73$ & 2 & 2510 & $8-9-73$ \\
7 & $5-3-73$ & 2 & 4892 & $11-27-73$ \\
8 & $5-3-73$ & 2 & 4892 & $11-27-73$ \\
9 & $5-3-73$ & 3 & 5016 & $12-4-73$ \\
10 & $5-3-73$ & 3 & 5016 & $12-4-73$ \\
\hline
\end{tabular}

${ }^{a}$ Set identifications:

1. $900^{\circ} \mathrm{C} ; 5000 \mathrm{hr}$; helium atmosphere; Ir, C, Pt, Hf $-1 \% \mathrm{Pt}-$ $0.5 \% \mathrm{Pd}$, Hastelloy $\mathrm{C}-276$, Haynes 25 , Haynes $188, \mathrm{ThO}_{2}$, $\mathrm{Pt}-20 \% \mathrm{Rh}$, and $\mathrm{Pt}-26 \% \mathrm{Rh}-8 \% \mathrm{~W}$.

2. $900^{\circ} \mathrm{C} ; 5000 \mathrm{hr}$; graphite, helium atmosphere; Ir, Pt, Hf $-1 \% \mathrm{Pt}-0.5 \% \mathrm{Pd}$, Hastelloy C-276, Haynes 25, Haynes 188, $\mathrm{ThO}_{2}, \mathrm{Pt}-20 \% \mathrm{Rh}$, and $\mathrm{Pt}-26 \% \mathrm{Rh}-8 \% \mathrm{~W}$.

3. $1100^{\circ} \mathrm{C} ; 2500 \mathrm{hr}$; graphite, helium atmosphere; Ir, Pt, $\mathrm{Pt}_{3} \mathrm{Ir}$, and $\mathrm{Pt}-26 \% \mathrm{Rh}-8 \% \mathrm{~W}-0.5 \% \mathrm{Ti}$.

4. $1100^{\circ} \mathrm{C} ; 2500 \mathrm{hr}$; dynamic vacuum; Ir, Pt, Pt ${ }_{3} \mathrm{Ir}, \mathrm{C}$, and $\mathrm{Pt}-26 \% \mathrm{Rh}-8 \% \mathrm{~W}-0.5 \% \mathrm{Ti}$.

5. $1100^{\circ} \mathrm{C} ; 2500 \mathrm{hr}$; helium atmosphere; Ir, Pt, Pt 3 Ir, C, and $\mathrm{Pt}-26 \% \mathrm{Rh}-8 \% \mathrm{~W}-0.5 \% \mathrm{Ti}$.

6. $1100^{\circ} \mathrm{C} ; 2500 \mathrm{hr}$; graphite, dynamic vacuum; Ir, Pt, Pt ${ }_{3} \mathrm{Ir}$, and $\mathrm{Pt}-26 \% \mathrm{Rh}-8 \% \mathrm{~W}-0.5 \% \mathrm{~T}$.

7. $1400^{\circ} \mathrm{C} ; 5000 \mathrm{hr}$; graphite, helium atmosphere; Ir, C, Mo, Mo- $46 \% \mathrm{Re}, \mathrm{Ta}, \mathrm{T}-111, \mathrm{~W}$, and $\mathrm{W}-26 \% \mathrm{Re}$.

8. $1400^{\circ} \mathrm{C} ; 5000 \mathrm{hr}$; dynamic vacuum; Ir, Mo, Mo-46\% Re, Ta, $\mathrm{T}-111, \mathrm{~W}$, and $\mathrm{W}-26 \% \mathrm{Re}$.

9. $1400^{\circ} \mathrm{C}$; $5000 \mathrm{hr}$; helium atmosphere; Ir, Mo, Mo- $46 \%$ Re, $\mathrm{Ta}, \mathrm{T}-111, \mathrm{~W}$, and $\mathrm{W}-26 \% \mathrm{Re}$.

10. $1400^{\circ} \mathrm{C}$; $5000 \mathrm{hr}$; graphite, dynamic vacuum; Ir, C, Mo, Mo-46\% Re, Ta, T-111, W, and $\mathrm{W}-26 \% \mathrm{Re}$. 


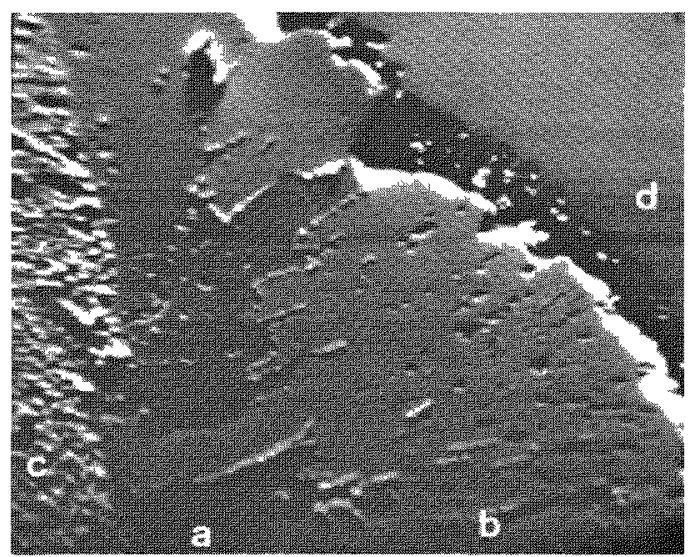

Backscattered Electrons

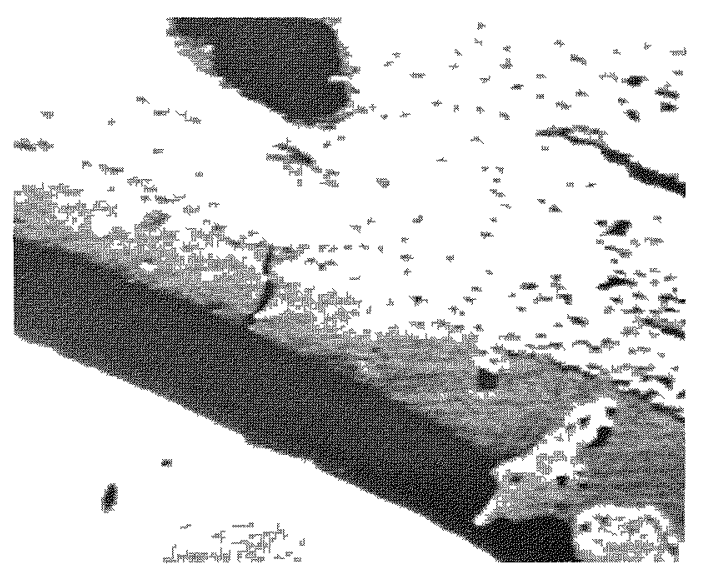

Backscattered Electrons

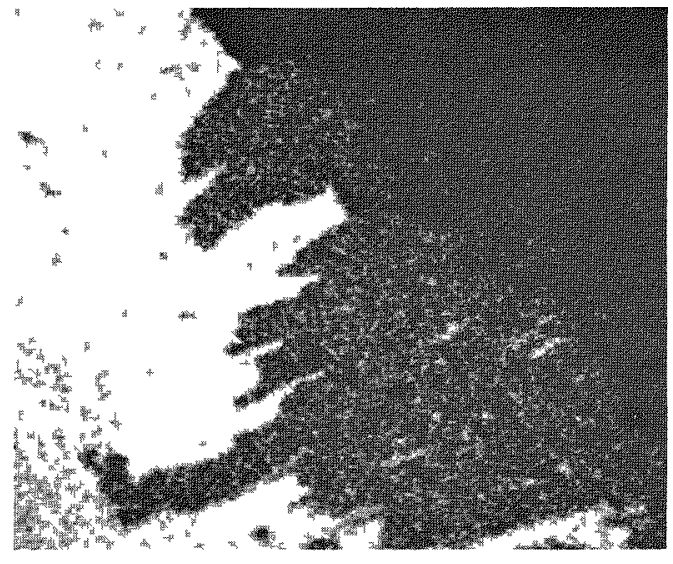

$\mathrm{Cm} \mathrm{Ma}_{\mathrm{a}}$

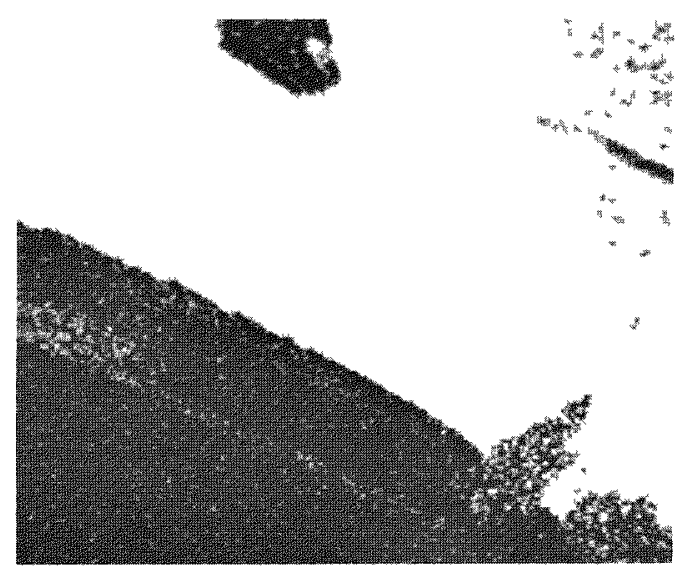

$\mathrm{CmMa}_{\mathrm{m}}$

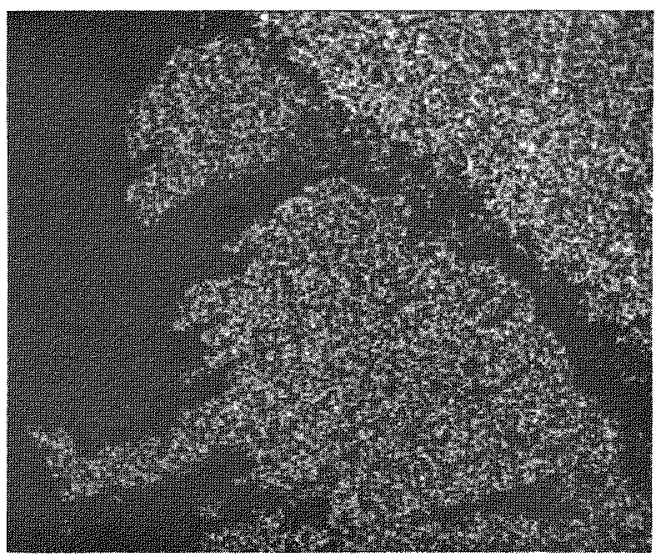

Pt Ma

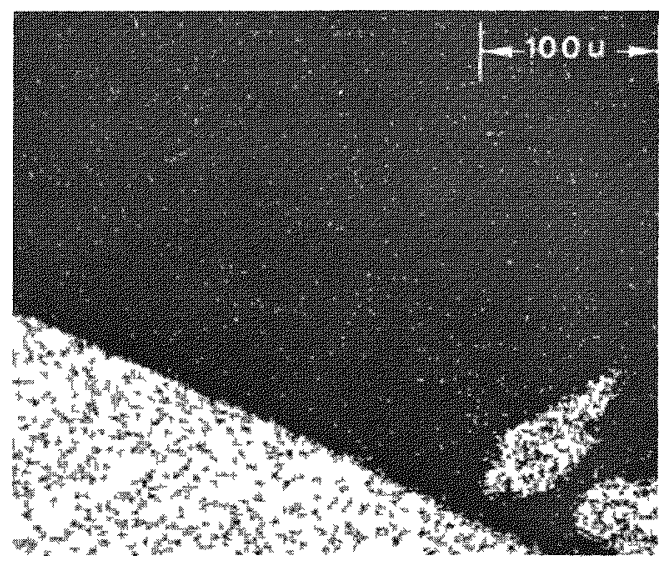

Pr Ma

Fig. 1. Electron-Beam Scanning Images of $\mathrm{Cm}_{2} \mathrm{O}_{3}-\mathrm{Pt}$ Compatibility Test.

$\begin{array}{lrrrrr} & \text { Area A } & \text { Area B } & \text { Area C } & \text { Area D } \\ \text { \% Concentration } & 95 \mathrm{Cm} & 72 \mathrm{Pt} & 95 \mathrm{Cm} & 100 \mathrm{Pt} \\ & 0 \mathrm{Pt} & 14 \mathrm{Cm} & 0 \mathrm{Pt} & \end{array}$


FY 1974 Compatibility Matrix

(T. A. Butler, J.R. Distefano, C. L. Ottinger)

A test system that will incorporate mechanical properties specimens for evaluation with ${ }^{244} \mathrm{Cm}_{2} \mathrm{O}_{3}$ has been designed ( $\mathrm{Fig}$. 2). A test package consisting of four sheet tensile specimens and two fuel frames containing two rectangular ${ }^{24}{ }^{4} \mathrm{Cm}_{2} \mathrm{O}_{3}$ samples is held together by two nuts and bolts made from the material being evaluated. Test conditions selected are as indicated below:

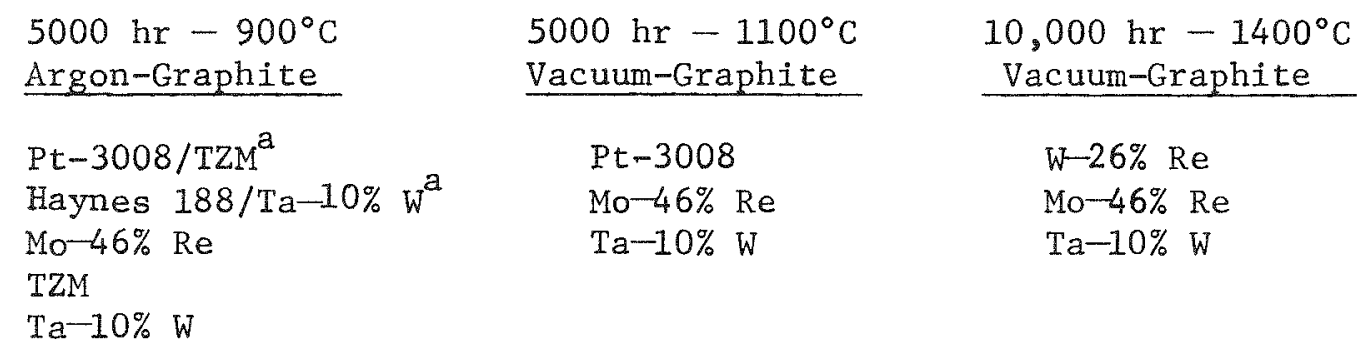

${ }^{a}$ Outer sealed container surrounding vented inner capsule.

Procurement and fabrication of test componentsare now underway. The alloys Haynes 188, Ta-10\% W, TZM, and $\mathrm{W}-26 \%$ Re are being obtained from commercial sources. The alloys Mo-46\% Re and Pt-3008 are not commercially available, and material is being prepared by melting, casting, and sheet rolling procedures. Procedures to form cylindrical tubes from sheet are also being developed for these materials.

Tensile specimens of all of the materials except $\mathrm{W}-26 \%$ Re are to be diepunched from sheet at room temperature. The $W-26 \%$ Re alloy tends to develop edge cracks when sheared, and, therefore, tensile specimens of this material will have to be prepared by machining and grinding operations.

In addition to the mechanical properties tests, two ceramic materials, $\mathrm{ZrO} 2$ and $\mathrm{Si}_{3} \mathrm{~N}_{4}$, will be tested with $2^{44} \mathrm{Cm}_{2} \mathrm{O}_{3}$ for $5000 \mathrm{hr}$ at $900^{\circ} \mathrm{C}$. Capsules will be vented to an argon atmosphere and will be in contact with graphite. The $\mathrm{ZrO}_{2}$ test specimen is rigidized felt, and the container material is $\mathrm{Y}_{2} \mathrm{O}_{3}$ stabilized $\mathrm{ZrO}_{2}$. The $\mathrm{Si}_{3} \mathrm{O}_{4}$ for these tests is to be supplied by Gulf General Atomic. Three disk specimens have been received, but containers have not yet been fabricated.

Fabrication procedures for the ${ }^{244} \mathrm{Cm}_{2} \mathrm{O}_{3}$ fuel pieces are being developed. The planned procedure uses a slotted die body and rectangular punch to form a ${ }^{244} \mathrm{Cm}_{2} \mathrm{O}_{3}$ fuel piece $1 / 2 \times 1 / 8 \times \sim 0.04 \mathrm{in}$. by hot pressing. Test pressings with $\mathrm{Gd}_{2} \mathrm{O}_{3}$ have given mixed results, but the problems are mechanical in nature and the technique should prove usable. 

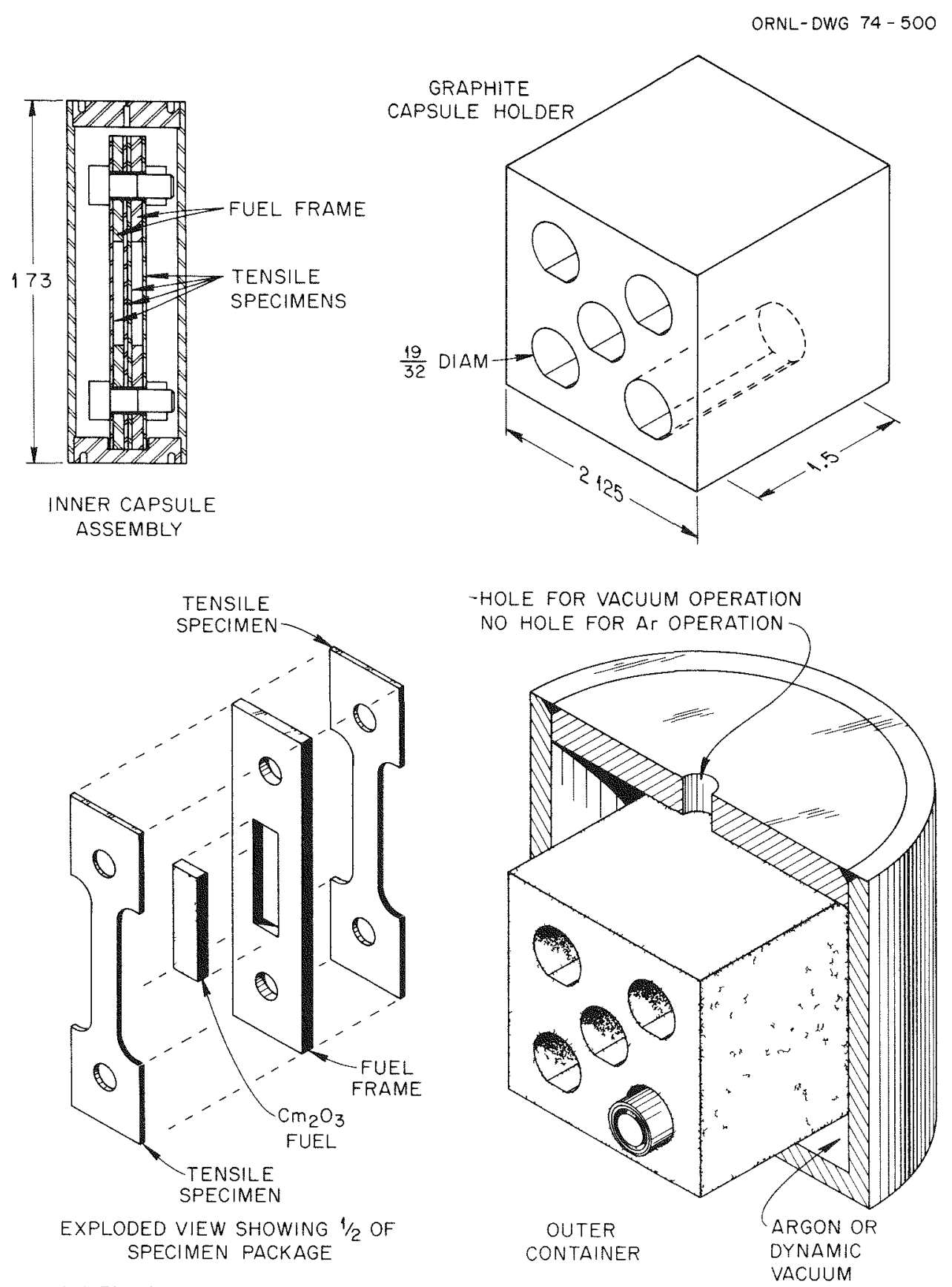

DIMENSIONS ARE IN INCHES

Fig. 2. ${ }^{244} \mathrm{Cm}_{2} \mathrm{O}_{3}$ Mechanical Properties Compatibility Test System. 
Compatibility With Ceramic Materials ( $P$. AngeZini)

The short-term ceramic compatibility experimental matrix started last quarter is given in Table 2. The results of experiments $A, B, E$, and $F$ have been reported previously. ${ }^{1}$ The other exposures were completed and examinations were started. After a 401-hr exposure of couples C, G, and I, a second $\mathrm{Cm}_{2} \mathrm{O}_{3}$ pellet/specimen set was placed on top of the original set in each capsule; then the exposure was continued for an additional $512 \mathrm{hr}$. In experiments $D, H$, and $J$, the fuel pellets were fabricated, loaded into the couples along with the proper specimens, and taken to temperature within an elapsed time of two days. The time was held to a minimum in order to minimize any possible deformation of pellets due to helium generation, thus providing better solid/solid contact between the pellets and the inserts. In addition to the fuel pellet, $\sim 150 \mathrm{mg}$ of powder obtained by crushing hot-pressed fuel pellets was placed in each capsule. Additional solid/solid contact area was expected to occur between the powder and the ceramic insert.

Table 2. ${ }^{244} \mathrm{Cm}_{2} \mathrm{O}_{3} /$ Ceramic Compatibility Experiments

\begin{tabular}{ccccc}
\hline Experiment & Material & $\begin{array}{c}\text { Temperature } \\
\left({ }^{\circ} \mathrm{C}\right)\end{array}$ & \multicolumn{2}{c}{ Time $(\mathrm{hr})$} \\
\hline $\mathrm{A}$ & & 1500 & 24 & 24 \\
$\mathrm{~B}$ & $\mathrm{ThO}_{2}$ & 1300 & 100 & 100 \\
$\mathrm{C}$ & $\mathrm{ThO}_{2}$ & 1500 & 500 & $512 / 913$ \\
$\mathrm{~T}$ & $\mathrm{ThO}_{2}$ & 1300 & 500 & 733 \\
$\mathrm{E}$ & $\mathrm{ZrO}_{2}$ & 1500 & 24 & 24 \\
$\mathrm{~F}$ & $\mathrm{ZrO}_{2}$ & 1300 & 100 & 100 \\
$\mathrm{G}$ & $\mathrm{ZrO}_{2}$ & 1500 & 500 & $512 / 913$ \\
$\mathrm{H}$ & $\mathrm{ZrO}_{2}$ & 1300 & 500 & 733 \\
$\mathrm{I}$ & $\mathrm{Al}_{2} \mathrm{O}_{3}$ & 1500 & 500 & $512 / 913$ \\
$\mathrm{~J}$ & $\mathrm{Al}_{2} \mathrm{O}_{3}$ & 1300 & 500 & 733 \\
\hline
\end{tabular}

Optical microscopy was completed on couples C, G, H, and I; preliminary examination of couples $\mathrm{D}$ and $\mathrm{J}$ was done.

Couple C $\left(\mathrm{ThO}_{2}, 512 / 913 \mathrm{hr}, 1500^{\circ} \mathrm{C}\right)$

This diffusion couple was seen to be cracked when it was removed from the heating furnace. When it was unloaded at HRLEL, the capsule of the diffusion couple had separated into three pieces. Two mounts were made of the most important pieces. Viewing these mounts from a low power microscope, one sees that extensive reaction did occur. Where the curium had reacted with the thoria, the thoria had a bluish color, and a concentration gradient was clearly evident. The thoria inserts in contact with the lower curia fuel pellet which had been exposed for a total of $913 \mathrm{hr}$ at $1500^{\circ} \mathrm{C}$ showed curium had diffused into the thoria to a distance $>30$ mils. The inserts in contact with the upper pellet which had been exposed 
at $1500^{\circ} \mathrm{C}$ for $512 \mathrm{hr}$ showed curium had diffused into the thoria to an extent of 15 mils. Also the lower fuel pellet was completely broken up. The upper fuel pellet was still in one piece; however, a reaction product could be seen in the fuel pellet.

Couple D $\left(\mathrm{ThO}_{2}, 733 \mathrm{hr}, 1300^{\circ} \mathrm{C}\right)$

A reaction occurred in the experiment with diffusion couple D. Again the reaction occurred to a greater extent between the $\mathrm{Cm}_{2} \mathrm{O}_{3}$ powder and insert than between the pellet and insert. A reaction zone $>6 \mathrm{mils}$ was seen in the $\mathrm{ThO}_{2}$ capsule and insert. The zone appeared to be blue in color.

Couple G $\left(\mathrm{ZrO}_{2}, 512 / 913 \mathrm{hr}, 1500^{\circ} \mathrm{C}\right)$

No extensive reaction areas could be seen in this diffusion couple as viewed at this time.

Couple $\mathrm{H}\left(\mathrm{ZrO}_{2}, 733 \mathrm{hr}, 1300^{\circ} \mathrm{C}\right)$

The optical microscopy was completed on diffusion couple $\mathrm{H}$. A dark area $\checkmark 3 \mathrm{mils}$ in thickness completely surrounding the ${ }^{244} \mathrm{Cm}_{2} \mathrm{O}_{3}$ pellet was recorded. This effect was noted previously in the other $\mathrm{ZrO}_{2}$ diffusion couples. Since this phenomenon seems to occur only in the $\mathrm{Cm}_{2} \mathrm{O}_{3}$ pellets exposed to $\mathrm{ZrO}_{2}$, it is an indication of a reaction.

Couple I $\left(\mathrm{Al}_{2} \mathrm{O}_{3}, 512 / 913 \mathrm{hr}, 1300^{\circ} \mathrm{C}\right)$

A reaction occurred in this diffusion couple. There were surface regions on both the curium oxide and aluminum oxide where extensive reaction occurred. Throughout the curium oxide pellet there was an interconnected linear second phase; the concentration of this phase within the fuel pellet decreased as the distance from the reaction area increased. This second phase did not exist in the as-fabricated pellet or in any of the previous diffusion couples which have been analyzed. Another concentration gradient seen as a varying grayish tone was observed in the aluminum oxide inserts and capsule. It appears as if there were almost thorough interdiffusion throughout the fuel pellet, inserts, and capsule.

Couple $\mathrm{J}\left(\mathrm{Al}_{2} \mathrm{O}_{3}, 733 \mathrm{hr}, 1300^{\circ} \mathrm{C}\right)$

The preliminary data from diffusion couple $\mathrm{J}$ indicated complete interdiffusion between inserts and fuel pellets. A definite discoloration of the $\mathrm{Al}_{2} \mathrm{O}_{3}$ inserts and parts of the $\mathrm{Al}_{2} \mathrm{O}_{3}$ container could be seen. Some cracking of the capsule also occurred. The ${ }^{244} \mathrm{Cm}_{2} \mathrm{O}_{3}$ powder placed at the bottom of the container was found to interact much more with the container than did the $\mathrm{Cm}_{2} \mathrm{O}_{3}$ pellet. This signifies that a much better contact area occurred between the $\mathrm{Cm}_{2} \mathrm{O}_{3}$ powder and $\mathrm{Al}_{2} \mathrm{O}_{3}$ insert than between the contact area of the pellet and insert. 
Free Energy Calculations $-\mathrm{Cm}_{2} \mathrm{O}_{3}$ With Haynes $188, \mathrm{Ta}-10 \% \mathrm{~W}$, and $\operatorname{TZM}^{2}(E . E$. Ketchen)

Reactions between $\mathrm{Cm}_{2} \mathrm{O}_{3}$ and the constituents of the alloys Haynes 188 , $\mathrm{Ta}-10 \% \mathrm{~W}$, and TZM were investigated from a thermodynamic viewpoint in the temperature range of $600-1300^{\circ} \mathrm{C}$. In all cases, the partial molar free energies of mixing for the constituents of the alloy were calculated using the method reported previously ${ }^{1}$ for the reaction of $\mathrm{Cm}_{2} \mathrm{O}_{3}$ and $\mathrm{PuO}_{2}$ in certain alloys. The free energies of formation for the oxides were calculated from a data compilation by Glassner ${ }^{2}$ and a review article by oetting. ${ }^{3}$ The free energies of $\mathrm{Pu}_{2} \mathrm{O}_{3}$ were used as stand-ins for those of $\mathrm{Cm}_{2} \mathrm{O}_{3}$. In calculating the heat of mixing, it was assumed that there is no compound formation between the constituents of the alloy.

Reaction of $\mathrm{Cm}_{2} \mathrm{O}_{3}$ With Haynes 188 - The results of the calculations of the partial molar free energies of mixing for the constituents in Haynes 188 are shown in Table 3. The composition of Haynes 188 is 41.87 atom \% Co, 26.50 atom \% Cr, 23.47 atom \% Ni, 4.77 atom \% W, 1.68 atom $\% \mathrm{Fe}, 0.86$ atom $\% \mathrm{Mn}, 0.44$ atom $\% \mathrm{Si}, 0.41$ atom $\% \mathrm{C}$, and 0.00004 atom \% La.

Table 3. Partial Molar Free Energies of Mixing of the Constituents in Haynes 188 Alloy

\begin{tabular}{lrrrrr}
\hline \multirow{2}{*}{ Component } & \multicolumn{5}{c}{$\Delta \bar{G}_{\mathrm{M}}(\mathrm{cal} / \mathrm{mole})$} \\
\cline { 2 - 6 } & $600^{\circ} \mathrm{C}$ & $800^{\circ} \mathrm{C}$ & $1000^{\circ} \mathrm{C}$ & $1200^{\circ} \mathrm{C}$ & $1300^{\circ} \mathrm{C}$ \\
\hline & & & & & \\
$\mathrm{Co}$ & 1,460 & 1,800 & 2,150 & 2,500 & 2,670 \\
$\mathrm{Cr}$ & 1,980 & 2,510 & 3,040 & 3,570 & 3,830 \\
$\mathrm{Ni}$ & 2,510 & 3,080 & 3,660 & 4,230 & 4,520 \\
$\mathrm{~W}$ & 5,030 & 6,240 & 7,450 & 8,660 & 9,260 \\
$\mathrm{Fe}$ & 7,090 & 8,710 & 10,340 & 11,960 & 12,770 \\
$\mathrm{Mn}$ & 8,230 & 10,120 & 12,020 & 13,910 & 14,860 \\
$\mathrm{Si}$ & 9,320 & 11,470 & 13,620 & 15,770 & 16,840 \\
$\mathrm{C}$ & 9,460 & 11,650 & 13,830 & 16,020 & 17,110 \\
$\mathrm{La}$ & 17,750 & 21,820 & 25,890 & 29,950 & 31,990 \\
& & & & &
\end{tabular}

The free energies of formation of $\mathrm{CoO}, \mathrm{Cr}_{2} \mathrm{O}_{3}, \mathrm{NiO}, \mathrm{WO}_{2}, \mathrm{Fe}_{3} \mathrm{O}_{4}, \mathrm{MnO}_{2}$, $\mathrm{SiO}_{2}, \mathrm{CO}_{2}, \mathrm{La}_{2} \mathrm{O}_{3}, \mathrm{Pu}_{2} \mathrm{O}_{3}$, and $\mathrm{PuO}_{2}$ were calculated; results are shown in Table 4 . 
Table 4. Gibbs Free Energy of Formation of Oxides Involved in Haynes 188/Curium Fuel Reactions

\begin{tabular}{lrrrrr}
\hline \multirow{2}{*}{ Constituents } & \multicolumn{5}{c}{$\Delta \mathrm{G}_{\mathrm{f}}(\mathrm{kcal} / \mathrm{mole})$} \\
\cline { 2 - 6 } & \multicolumn{6}{c}{$800^{\circ} \mathrm{C}$} & \multicolumn{6}{c}{$800^{\circ} \mathrm{C}$} & $1000^{\circ} \mathrm{C}$ & $1200^{\circ} \mathrm{C}$ & $1300^{\circ} \mathrm{C}$ \\
\hline $\mathrm{CoO}$ & -39.46 & -35.37 & -31.02 & -27.08 & -24.96 \\
$\mathrm{Cr} 2 \mathrm{O}_{3}$ & -203.92 & -189.81 & -175.72 & -161.67 & -154.63 \\
$\mathrm{NiO}$ & -39.06 & -35.01 & -31.01 & -27.10 & -25.15 \\
$\mathrm{WO}_{2}$ & -101.16 & -93.85 & -86.78 & -79.96 & -76.80 \\
$\mathrm{Fe}_{3} \mathrm{O}_{4}$ & -199.79 & -185.20 & -170.88 & -156.61 & -149.47 \\
$\mathrm{MnO}_{2}$ & -76.82 & -73.30 & -69.76 & -66.23 & -64.27 \\
$\mathrm{SiO}_{2}$ & -172.92 & -164.60 & -156.33 & -148.10 & -144.00 \\
$\mathrm{CO}_{2}$ & -94.62 & -94.66 & -94.70 & -94.73 & -94.74 \\
$\mathrm{La}_{2} \mathrm{O}_{3}$ & -373.84 & -361.82 & -349.69 & -337.23 & -331.04 \\
$\mathrm{Pu}_{2} \mathrm{O}_{3}$ & -352.12 & -339.32 & -326.94 & -314.98 & -309.15 \\
$\mathrm{PuO}_{2}$ & -215.55 & -207.05 & -198.70 & -190.53 & -186.50 \\
\hline
\end{tabular}

The free energies from Tables 3 and 4 were used to calculate the free energies for Eqs. 1-18. Results are shown in Tables 5 and 6 .

$$
\begin{aligned}
& 3 \mathrm{Co}\left(\text { in Haynes } 188 \text { ) (s) }+\mathrm{Cm}_{2} \mathrm{O}_{3}(\mathrm{~s}) \rightarrow 2 \mathrm{Cm}(\mathrm{s})+3 \mathrm{CoO}(\mathrm{s})\right. \\
& \mathrm{Co}\left(\text { in Haynes 188) (s) }+2 \mathrm{PuO}_{2}(\mathrm{~s}) \rightarrow \mathrm{Pu}_{2} \mathrm{O}_{3}(\mathrm{~s})+\mathrm{CoO}(\mathrm{s})\right. \\
& 2 \mathrm{Cr} \text { (in Haynes 188) (s) }+\mathrm{Cm}_{2} \mathrm{O}_{3}(\mathrm{~s}) \rightarrow 2 \mathrm{Cm}(\mathrm{s})+\mathrm{Cr}_{2} \mathrm{O}_{3}(\mathrm{~s}) \\
& 2 \mathrm{Cr} \text { (in Haynes 188) (s) }+6 \mathrm{PuO}_{2}(\mathrm{~s}) \rightarrow 3 \mathrm{Pu}_{2} \mathrm{O}_{3}(\mathrm{~s})+\mathrm{Cr}_{2} \mathrm{O}_{3}(\mathrm{~s}) \\
& 3 \mathrm{Ni} \text { (in Haynes 188) (s) }+\mathrm{Cm}_{2} \mathrm{O}_{3}(\mathrm{~s}) \rightarrow 2 \mathrm{Cm}(\mathrm{s})+3 \mathrm{NiO}(\mathrm{s}) \\
& \mathrm{Ni}(\text { in Haynes } 188)(\mathrm{s})+2 \mathrm{PuO}_{2}(\mathrm{~s}) \rightarrow \mathrm{Pu}_{2} \mathrm{O}_{3}(\mathrm{~s})+\mathrm{NiO}(\mathrm{s}) \\
& 3 \mathrm{~W}\left(\text { in Haynes 188) (s) }+2 \mathrm{Cm}_{2} \mathrm{O}_{3}(\mathrm{~s}) \rightarrow 4 \mathrm{Cm}(\mathrm{s})+3 \mathrm{WO}_{2}(\mathrm{~s})\right. \\
& \mathrm{W}\left(\text { in Haynes 188) }(\mathrm{s})+4 \mathrm{PuO}_{2}(\mathrm{~s}) \rightarrow 2 \mathrm{Pu}_{2} \mathrm{O}_{3}(\mathrm{~s})+\mathrm{WO}_{2}(\mathrm{~s})\right. \\
& 9 \mathrm{Fe} \text { (in Haynes 188) (s) }+4 \mathrm{Cm}_{2} \mathrm{O}_{3}(\mathrm{~s}) \rightarrow 8 \mathrm{Cm}(\mathrm{s})+3 \mathrm{Fe}_{3} \mathrm{O}_{4}(\mathrm{~s}) \\
& 3 \mathrm{Fe}\left(\text { in Haynes 188) }(\mathrm{s})+8 \mathrm{PuO}_{2}(\mathrm{~s}) \rightarrow 4 \mathrm{Pu}_{2} \mathrm{O}_{3}(\mathrm{~s})+\mathrm{Fe}_{3} \mathrm{O}_{4}(\mathrm{~s})\right. \\
& 3 \mathrm{Mn} \text { (in Haynes 188) (s) }+\mathrm{Cm}_{2} \mathrm{O}_{3}(\mathrm{~s}) \rightarrow 2 \mathrm{Cm}(\mathrm{s})+3 \mathrm{MnO}(\mathrm{s}) \\
& \mathrm{Mn}\left(\text { In Haynes 188) (s) }+2 \mathrm{PuO}_{2}(\mathrm{~s}) \rightarrow \mathrm{Pu}_{2} \mathrm{O}_{3}(\mathrm{~s})+\mathrm{MnO}(\mathrm{s})\right. \\
& 3 \mathrm{Si} \text { (in Haynes 188) (s) }+2 \mathrm{Cm}_{2} \mathrm{O}_{3}(\mathrm{~s}) \rightarrow 4 \mathrm{Cm}(\mathrm{s})+3 \mathrm{SiO}_{2}(\mathrm{~s}) \\
& \mathrm{Si}\left(\text { in Haynes 188) }(\mathrm{s})+4 \mathrm{PuO}_{2}(\mathrm{~s}) \rightarrow 2 \mathrm{Pu}_{2} \mathrm{O}_{3}(\mathrm{~s})+\mathrm{SiO}_{2}(\mathrm{~s})\right. \\
& 3 \mathrm{C}(\text { in Haynes } 188)(\mathrm{s})+2 \mathrm{Cm}_{2} \mathrm{O}_{3}(\mathrm{~s}) \rightarrow 4 \mathrm{Cm}(\mathrm{s})+3 \mathrm{CO}_{2}(\mathrm{~g}) \\
& \mathrm{C}\left(\text { in Haynes 188) }(\mathrm{s})+4 \mathrm{PuO}_{2}(\mathrm{~s}) \rightarrow 2 \mathrm{Pu}_{2} \mathrm{O}_{3}(\mathrm{~s})+\mathrm{CO}_{2}(\mathrm{~g})\right. \\
& 2 \mathrm{La} \text { (in Haynes 188) (s) }+\mathrm{Cm}_{2} \mathrm{O}_{3}(\mathrm{~s}) \rightarrow 2 \mathrm{Cm}(\mathrm{s})+\mathrm{La}_{2} \mathrm{O}_{3}(\mathrm{~s}) \\
& 2 \mathrm{La} \text { (in Haynes 188) (s) }+6 \mathrm{PuO}_{2}(\mathrm{~s}) \rightarrow 3 \mathrm{Pu}_{2} \mathrm{O}_{3}(\mathrm{~s})+\mathrm{La}_{2} \mathrm{O}_{3}(\mathrm{~s})
\end{aligned}
$$


Table 5. Free Energies of Reaction for Haynes $188 / \mathrm{Cm}_{2} \mathrm{O}_{3}$ Reactions

\begin{tabular}{crrrrr}
\hline \multirow{2}{*}{ Equation } & \multicolumn{5}{c}{$\Delta \mathrm{G}_{\mathrm{r}} \mathrm{C}\left(\mathrm{ca} / \mathrm{mole}\right.$ of $\left.\mathrm{Cm}_{2} \mathrm{O}_{3}\right)$} \\
\cline { 2 - 6 } & $600^{\circ} \mathrm{C}$ & $800^{\circ} \mathrm{C}$ & $1000^{\circ} \mathrm{C}$ & $1200^{\circ} \mathrm{C}$ & $1300^{\circ} \mathrm{C}$ \\
1 & 238,500 & 238,620 & 240,320 & 241,240 & 242,380 \\
3 & 152,170 & 154,530 & 157,300 & 160,440 & 162,380 \\
5 & 242,460 & 243,540 & 244,880 & 246,390 & 247,270 \\
7 & 207,920 & 207,910 & 207,940 & 300,030 & 207,840 \\
9 & 218,220 & 220,020 & 222,040 & 224,430 & 225,780 \\
11 & 146,340 & 149,790 & 153,710 & 158,020 & 160,930 \\
13 & 106,720 & 109,620 & 112,870 & 116,480 & 118,410 \\
15 & 224,380 & 214,800 & 205,560 & 196,910 & 192,710 \\
17 & 13,780 & 21,140 & 29,020 & 37,660 & 42,080 \\
& & & & & \\
\hline
\end{tabular}

Table 6. Free Energies of Reaction for Haynes $188 / \mathrm{PuO}_{2}$ Reactions

\begin{tabular}{crrrrr}
\hline \multirow{2}{*}{ Equation } & \multicolumn{5}{c}{$\left.\Delta \mathrm{G}_{\mathrm{r}} \mathrm{( \textrm {cal } / \mathrm { mole } \text { of }} \mathrm{PuO}_{2}\right)$} \\
\cline { 2 - 6 } & \multicolumn{1}{c}{$600^{\circ} \mathrm{C}$} & \multicolumn{1}{c}{$800^{\circ} \mathrm{C}$} & \multicolumn{1}{c}{$1000^{\circ} \mathrm{C}$} & \multicolumn{1}{c}{$1200^{\circ} \mathrm{C}$} & $1300^{\circ} \mathrm{C}$ \\
\hline 2 & 20,490 & 20,600 & 20,800 & 20,750 & 20,780 \\
4 & 6,110 & 6,590 & 6,960 & 7,280 & 7,470 \\
6 & 21,210 & 21,420 & 21,560 & 21,610 & 21,620 \\
8 & 15,450 & 15,480 & 15,400 & 15,210 & 15,060 \\
10 & 17,170 & 17,500 & 17,750 & 17,950 & 18,050 \\
12 & 5,190 & 5,800 & 6,370 & 6,880 & 7,230 \\
14 & $-1,420$ & -900 & -440 & -40 & 150 \\
16 & 18,200 & 16,610 & 15,020 & 13,360 & 12,540 \\
18 & $-16,900$ & $-15,650$ & $-14,420$ & $-13,180$ & $-12,580$ \\
& & & & & \\
\hline
\end{tabular}

Since the free energies of $\mathrm{Eq} \cdot 14$ and $\mathrm{Eq} \cdot 18$ are negative, it appears that the silicon and lanthanum of the Haynes 188 alloy should react with the $\mathrm{PuO}_{2}$ of the ${ }^{244} \mathrm{Cm}_{2} \mathrm{O}_{3}$ product over the $600-1300^{\circ} \mathrm{C}$ temperature range. It should be noted that it was assumed there would be no compound formation between the components of the alloy or with the curium metal formed. Also no account was taken for possible oxygen solubility in the alloy. Experimental verification of the interaction of Haynes 188 alloy with the curium product is needed.

Reaction of $\mathrm{Cm}_{2} \mathrm{O}_{3}$ With $\mathrm{Ta}-10 \% \mathrm{~W} \mathrm{Alloy} \mathrm{-} \mathrm{The} \mathrm{results} \mathrm{of} \mathrm{the} \mathrm{calculations}$ of the partial molar free energies of mixing for tantalum and tungsten are shown in Table 7. The composition of $\mathrm{Ta}-10 \% \mathrm{~W}$ is 90.14 atom $\% \mathrm{Ta}$ and 9.86 atom $\% \mathrm{~W}$. 
Table 7. Partial Molar Free Energies of Mixing of Tungsten and Tantalum in $\mathrm{Ta}-10 \% \mathrm{~W}$ Alloy

\begin{tabular}{crrrrr}
\hline \multirow{2}{*}{ Constituents } & \multicolumn{5}{c}{$-\Delta \overline{\mathrm{G}}_{\mathrm{M}}(\mathrm{cal} / \mathrm{mole})$} \\
\cline { 2 - 6 } & $600^{\circ} \mathrm{C}$ & $800^{\circ} \mathrm{C}$ & $1000^{\circ} \mathrm{C}$ & $1200^{\circ} \mathrm{C}$ & $1300^{\circ} \mathrm{C}$ \\
\hline \multirow{2}{*}{$\mathrm{Ta}$} & 170 & 220 & 260 & 300 & 320 \\
$\mathrm{~W}$ & 3,960 & 4,880 & 5,800 & 6,720 & 7,180
\end{tabular}

The free energies of formation of $\mathrm{Ta}_{2} \mathrm{O}_{5}, \mathrm{WO}_{2}, \mathrm{Pu}_{2} \mathrm{O}_{3}$, and $\mathrm{PuO}_{2}$ were calculated; results are shown in Table 8 .

Table 8. Gibbs Free Energy of Formation of Oxides Involved in $\mathrm{Ta}-10 \% \mathrm{~W} /$ Curium Fuel Reactions

\begin{tabular}{lrrrrr}
\hline \multirow{2}{*}{ Compound } & \multicolumn{5}{c}{$-\Delta \mathrm{G}_{\mathrm{f}}(\mathrm{kcal} / \mathrm{mole})$} \\
\cline { 2 - 6 } & $600^{\circ} \mathrm{C}$ & $800^{\circ} \mathrm{C}$ & $1000^{\circ} \mathrm{C}$ & $1200^{\circ} \mathrm{C}$ & $1300^{\circ} \mathrm{C}$ \\
\hline $\mathrm{Ta}_{2} \mathrm{O}_{5}$ & 395.69 & 374.82 & 354.18 & 333.75 & 323.63 \\
$\mathrm{WO}_{2}$ & 101.16 & 93.85 & 86.78 & 79.96 & 76.80 \\
$\mathrm{Pu}_{2} \mathrm{O}_{3}{ }^{\mathrm{a}}$ & 352.12 & 339.32 & 326.94 & 314.98 & 309.15 \\
$\mathrm{PuO}_{2}$ & 215.55 & 207.05 & 198.70 & 190.53 & 186.50
\end{tabular}

Used as a stand-in for $\mathrm{Cm}_{2} \mathrm{O}_{3}$.

The free energies from Tables 7 and 8 were used to calculate the free energies for Eqs. 19-22. Results are shown in Table 9.

$$
\begin{aligned}
& 6 \mathrm{Ta}(\text { in } \mathrm{Ta}-10 \% \mathrm{~W})(\mathrm{s})+5 \mathrm{Cm}_{2} \mathrm{O}_{3}(\mathrm{~s}) \rightarrow 3 \mathrm{Ta}_{2} \mathrm{O}_{5}(\mathrm{~s})+10 \mathrm{Cm}(\mathrm{s}) \\
& 2 \mathrm{Ta}(\text { in } \mathrm{Ta}-10 \% \mathrm{~W})(\mathrm{s})+10 \mathrm{PuO}_{2}(\mathrm{~s}) \rightarrow \mathrm{Ta}_{2} \mathrm{O}_{5}(\mathrm{~s})+5 \mathrm{Pu}_{2} \mathrm{O}_{3}(\mathrm{~s}) \\
& 3 \mathrm{~W}(\text { in } \mathrm{Ta}-10 \% \mathrm{~W})(\mathrm{s})+2 \mathrm{Cm}_{2} \mathrm{O}_{3}(\mathrm{~s}) \rightarrow 3 \mathrm{WO}_{2}(\mathrm{~s})+4 \mathrm{Cm}(\mathrm{s}) \\
& \mathrm{W}(\text { in } \mathrm{Ta}-10 \% \mathrm{~W})(\mathrm{s})+4 \mathrm{PuO}_{2}(\mathrm{~s}) \rightarrow \mathrm{WO}_{2}(\mathrm{~s})+2 \mathrm{Pu}_{2} \mathrm{O}_{3}(\mathrm{~s})
\end{aligned}
$$

Table 9. Free Energies of Reaction ror $\mathrm{Ta}-10 \% \mathrm{~W} /$ Curium Fuel Reactions

\begin{tabular}{lrrrrr}
\hline \multirow{2}{*}{ Equation } & \multicolumn{5}{c}{$\Delta \mathrm{G}_{\mathrm{I}}\left(\mathrm{kcal} / \mathrm{mole}\right.$ of $\mathrm{Cm}_{2} \mathrm{O}_{3}$ or $\left.\mathrm{PuO}_{2}\right)$} \\
\cline { 2 - 6 } & \multicolumn{6}{c}{$600^{\circ} \mathrm{C}$} & $800^{\circ} \mathrm{C}$ & $1000^{\circ} \mathrm{C}$ & $1200^{\circ} \mathrm{C}$ & $1300^{\circ} \mathrm{C}$ \\
\hline 19 & 114.91 & 114.96 & 114.74 & 115.09 & 115.35 \\
20 & -0.49 & -0.54 & -1.32 & -2.76 & -3.57 \\
21 & 206.31 & 205.86 & 205.47 & 205.12 & 204.72 \\
22 & 15.18 & 15.14 & 14.99 & 14.73 & 14.54 \\
\hline
\end{tabular}


Since the free energies for Eq. 20 are negative it appears that the $\mathrm{PuO}_{2}$ of the curium product will react with the tantalum of the $\mathrm{Ta}-10 \% \mathrm{~W}$ alloy over the $600-1300^{\circ} \mathrm{C}$ temperature range. It should be noted that it was assumed there would be no compound formation between the tantalum and tungsten of the alloy or between the tantalum and tungsten with the curium metal that might be formed. Also no account was taken for possible oxygen solubility in the alloy. Experimental verification of the interaction of $\mathrm{Ta}-10 \% \mathrm{~W}$ alloy with the curium product is needed.

Reaction of $\mathrm{Cm}_{2} \mathrm{O}_{3}$ with TZM Alloy - The partial molar free energies of mixing of the constituents in TZM $(99.002$ atom \% Mo, 0.997 atom \% Ti, and 0.0008 atom $\% \mathrm{Zr}$ ) were calculated. The results are shown in Table 10.

Table 10. Partial Molar Free Energies of Mixing of Constituents in TZM

\begin{tabular}{crrrrr}
\hline \multirow{2}{*}{ Constituents } & \multicolumn{5}{c}{$-\Delta \overline{\mathrm{GM}}(\mathrm{cal} / \mathrm{mole})$} \\
\cline { 2 - 6 } & $600^{\circ} \mathrm{C}$ & $800^{\circ} \mathrm{C}$ & $1000^{\circ} \mathrm{C}$ & $1200^{\circ} \mathrm{C}$ & $1300^{\circ} \mathrm{C}$ \\
\hline Mo & 16 & 20 & 24 & 28 & 30 \\
Ti & 7,870 & 9,710 & 11,540 & 13,370 & 14,290 \\
Zr & 20,280 & 24,930 & 29,580 & 34,320 & 36,550 \\
\hline
\end{tabular}

The free energies of formation of $\mathrm{MoO}_{2}$, TiO, $\mathrm{ZrO}_{2}, \mathrm{Pu}_{2} \mathrm{O}_{3}$, and $\mathrm{PuO}_{2}$ were calculated; results are shown in Table 11.

Table 11. Gibbs Free Energy of Formation of Oxides Involved in TZM/Curium Fuel Reactions

\begin{tabular}{lrrrrr}
\hline \multirow{2}{*}{ Compound } & \multicolumn{5}{c}{$\Delta \mathrm{G}_{\mathrm{f}}(\mathrm{kcal} / \mathrm{mole})$} \\
\cline { 2 - 6 } & \multicolumn{6}{c}{$600^{\circ} \mathrm{C}$} & $800^{\circ} \mathrm{C}$ & $1000^{\circ} \mathrm{C}$ & $1200^{\circ} \mathrm{C}$ & $1300^{\circ} \mathrm{C}$ \\
\hline $\mathrm{MoO}_{2}$ & 95.60 & 87.71 & 80.36 & 72.94 & 69.27 \\
$\mathrm{TiO}^{\mathrm{ZrO}}$ & 103.78 & 99.38 & 95.08 & 90.87 & 88.81 \\
$\mathrm{Pu}_{2} \mathrm{O}_{3} \mathrm{a}$ & 221.71 & 212.82 & 203.85 & 194.96 & 190.66 \\
$\mathrm{PuO}_{2}$ & 352.12 & 339.32 & 326.94 & 314.98 & 309.15 \\
& 215.55 & 207.05 & 198.70 & 190.53 & 186.50
\end{tabular}

${ }^{a} \mathrm{Pu}_{2} \mathrm{O}_{3}$ used as a stand-in for $\mathrm{Cm}_{2} \mathrm{O}_{3}$.

The free energies from Tables 10 and 11 were used to calculate the free energies for Eqs. 23-28. Results are shown in Table 12.

$$
\begin{aligned}
& 3 \mathrm{Mo}\left(\text { in TZM alloy) (s) }+2 \mathrm{Cm}_{2} \mathrm{O}_{3}(\mathrm{~s}) \rightarrow 3 \mathrm{MoO}_{2}(\mathrm{~s})+4 \mathrm{Cm}(\mathrm{s})\right. \\
& \mathrm{Mo}\left(\text { in TZM alloy) (s) }+4 \mathrm{PuO}_{2}(\mathrm{~s}) \rightarrow \mathrm{MoO}_{2}(\mathrm{~s})+2 \mathrm{Pu}_{2} \mathrm{O}_{3}(\mathrm{~s})\right. \\
& 3 \mathrm{Ti}\left(\text { in TZM alloy) (s) }+\mathrm{Cm}_{2} \mathrm{O}_{3}(\mathrm{~s}) \rightarrow 3 \mathrm{TiO}(\mathrm{s})+2 \mathrm{Cm}(\mathrm{s})\right.
\end{aligned}
$$




$$
\begin{aligned}
& \mathrm{Ti}\left(\text { in TZM alloy) (s) }+2 \mathrm{PuO}_{2}(\mathrm{~s}) \rightarrow \mathrm{TiO}(\mathrm{s})+\mathrm{Pu}_{2} \mathrm{O}_{3}(\mathrm{~s})\right. \\
& 3 \mathrm{Zr}\left(\text { in TZM alloy) (s) }+2 \mathrm{Cm}_{2} \mathrm{O}_{3}(\mathrm{~s}) \rightarrow 3 \mathrm{ZrO}_{2}(\mathrm{~s})+4 \mathrm{Cm}(\mathrm{s})\right. \\
& \mathrm{Zr}\left(\text { in TZM alloy) (s) }+4 \mathrm{PuO}_{2}(\mathrm{~s}) \rightarrow \mathrm{ZrO}_{2}(\mathrm{~s})+2 \mathrm{Pu}_{2} \mathrm{O}_{3}(\mathrm{~s})\right.
\end{aligned}
$$

Table 12. Free Energies of Reaction for TZM/Curium Fuel Reactions

\begin{tabular}{crrrrr}
\hline \multirow{2}{*}{ Equation } & \multicolumn{5}{c}{$\Delta \mathrm{G}_{\mathrm{r}}\left(\mathrm{kcal} / \mathrm{mole}\right.$ of $\mathrm{Cm}_{2} \mathrm{O}_{3}$ or $\left.\mathrm{PuO}_{2}\right)$} \\
\cline { 2 - 6 } & $600^{\circ} \mathrm{C}$ & \multicolumn{1}{c}{$800^{\circ} \mathrm{C}$} & \multicolumn{1}{c}{$1000^{\circ} \mathrm{C}$} & $1200^{\circ} \mathrm{C}$ & $1300^{\circ} \mathrm{C}$ \\
\hline 23 & 208.84 & 207.49 & 206.44 & 205.62 & 205.29 \\
24 & 15.59 & 15.41 & 15.15 & 14.81 & 14.63 \\
25 & 66.42 & 70.54 & 76.32 & 81.89 & 85.59 \\
26 & -8.45 & -7.45 & -6.54 & -5.71 & -5.33 \\
27 & 49.98 & 57.49 & 65.53 & 73.88 & 77.98 \\
28 & -10.87 & -9.59 & -8.33 & -7.14 & -6.59 \\
\hline
\end{tabular}

Since the free energies for Eqs. 26 and 28 are negative, the $\mathrm{PuO}_{2}$ of the ${ }^{244} \mathrm{Cm}_{2} \mathrm{O}_{3}$ product would be expected to react with the titanium and zirconium in TZM alloy over the $600-1300^{\circ} \mathrm{C}$ temperature range. It should be repeated again that it was assumed there is no compound formation between the Mo, $\mathrm{Ti}$, or $\mathrm{Zr}$ of the alloy or between them and the curium metal. Also, no account was taken for the oxygen solubility in the TZM. Experimental verification of the interaction of the product with TZM is needed.

Effect of Oxygen Solubility in Container Alloys on Interaction With Curium Oxide Heat Sources (E. E. Ketchen)

Thermodynamic calculations have been made to investigate the reaction of curium oxide heat source material $\left(5 \% \mathrm{PuO}_{2}\right)$ with a number of possible container alloys. Since the free energy of decomposition of $\mathrm{PuO}_{2}$ to $\mathrm{Pu}_{2} \mathrm{O}_{3}$ and oxygen is less than the free energy of the decomposition of $\mathrm{Cm}_{2} \mathrm{O}_{3}$ to curium and oxygen, the $\mathrm{PuO}_{2}$ decomposition process is the major process that would furnish oxygen to react with the container material. For example, all of the constituents of TZM ( $\mathrm{Ti}, \mathrm{Zr}, \mathrm{Mo}$ ) are expected to react with $\mathrm{PuO}_{2}$ but not with $\mathrm{Cm}_{2} \mathrm{O}_{3}$ in the temperature range from 800 to $1300^{\circ} \mathrm{C}$.

Haynes 188 alloy $(41.87$ atom \% Co, 26.50 atom \% Cr, 23.47 atom \% Ni, 4.77 atom $\% \mathrm{~W}, 1.68$ atom $\% \mathrm{Fe}, 0.86$ atom $\% \mathrm{Mn}, 0.44$ atom $\% \mathrm{Si}, 0.41$ atom $\% \mathrm{C}$, and 0.00004 atom \% La) was found to be one of the alloys, by free energy calculations, that has low percentage components ( $\mathrm{Si}$ and $\mathrm{La}$ ) that should react with $\mathrm{PuO}_{2}$. The silicon and lanthanum should react with the $\mathrm{PuO}_{2}$ if not protected by other elements. This reaction could occur if oxygen can be transmitted in the alloy to the lanthanum and silicon atoms. The solubility of oxygen and its diffusion rate in the alloy are the two factors that determine the speed of the reaction of oxygen with the low 
percentage components. Generally it is assumed that the oxygen diffuses through the metal as a monoatomic gas.

When $\mathrm{PuO}_{2}$ is heated it loses oxygen and passes through a series of intermediate compositions to $\mathrm{Pu}_{2} \mathrm{O}_{3}$. The first oxygen is easiest to remove; at each succeeding composition the oxygen is more difficult to remove as the $\mathrm{Pu}_{2} \mathrm{O}_{3}$ composition is approached. This effect can be seen by comparing the equilibrium partial oxygen pressure over $\mathrm{PuO}_{2}$ with the average equilibrium oxygen pressure for the decomposition of $\mathrm{PuO}_{2}$ to $\mathrm{Pu}_{2} \mathrm{O}_{3}$. The pressures, which are shown in Table 13, were calculated from data by F. L. Oetting ${ }^{3}$ and R. A. Kent. ${ }^{4}$ For example, the oxygen pressure at $1000^{\circ} \mathrm{C}$ in equilibrium with $\mathrm{PuO}_{2}\left(9.42 \times 10^{-19} \mathrm{~atm}\right)$ is much higher than the average decomposition pressure calculated from the free energy of reaction of $\mathrm{PuO}_{2}$ to give $\mathrm{Pu}_{2} \mathrm{O}_{3}$ $\left(6.40 \times 10^{-25} \mathrm{~atm}\right)$. Also, it is evident from the low pressures in Table 13 that any mechanism by which a small quantity of oxygen is removed from the atmosphere above the $\mathrm{PuO}_{2}$ helps to decompose the $\mathrm{PuO}_{2}$. The $\mathrm{PuO}_{2}$ decomposition is aided by the oxygen solubility and oxygen diffusion in the container material.

Table 13. Equilibrium Oxygen Partial Pressures $\mathrm{Above}^{\mathrm{PuO}_{2}}$ and Average Equilibrium Oxygen Pressure for $\mathrm{PuO}_{2}$ Decomposition to $\mathrm{Pu}_{2} \mathrm{O}_{3}$

\begin{tabular}{ccr}
\hline $\begin{array}{c}\text { Temperature } \\
\left({ }^{\circ} \mathrm{C}\right)\end{array}$ & \multicolumn{2}{c}{ Equilibrium } \\
\cline { 2 - 3 } 600 & $1.88 \times 10^{-41}$ & $2.96 \times 10^{-40}$ \\
800 & $5.56 \times 10^{-28}$ & $3.50 \times 10^{-31}$ \\
1000 & $9.42 \times 10^{-19}$ & $6.40 \times 10^{-25}$ \\
1200 & $4.93 \times 10^{-12}$ & $2.49 \times 10^{-20}$ \\
1300 & $2.56 \times 10^{-9}$ & $1.81 \times 10^{-18}$ \\
\hline
\end{tabular}

Since Table 13 shows that there is a marked difference between the equilibrium partial pressure of oxygen above $\mathrm{PuO}_{2}$ and the pressure of oxygen due to the free energy change going from $\mathrm{PuO}_{2}$ to $\mathrm{Pu}_{2} \mathrm{O}_{3}$, it is evident that the calculations made in past reports on the free energy of reaction between the alloys and $\mathrm{PuO}_{2}$ may be too conservative in predicting some reaction between $\mathrm{PuO}_{2}$ and the alloy. However, since the initial equilibrium partial pressure above $\mathrm{PuO}_{2}$ decreases so rapidly as it loses oxygen, ${ }^{4}$ the estimates are probably still good.

Even though the free energy for the reaction of $\mathrm{PuO}_{2}$ with the container material is not favorable, the oxygen solubility and oxygen diffusion process can cause the reduction of plutonium oxide. That is, the equilibrium pressure of oxygen in the container above $\mathrm{PuO}_{2}$ may be below the concentration of oxygen needed to react with the container material, but the oxygen solubility and oxygen diffusion through the container wall can result in some $\mathrm{PuO}_{2}$ reduction. 
In general, more information is needed on the solubility of oxygen in the container material. The reported solubility of oxygen in the alloys may not be the true oxygen solubility in the metal but a combination of the true solubility and the solubility of a metal oxide. These oxygen and metal oxide solubility phenomena have been reported in tantalum metal by $S$. Stecura. ${ }^{5}$ Actual tantalum oxides were identified in the material after the metal had been dissolved. This occurred both at the reported solubility limit and well below this limit.

In conclusion, the term solubility of oxygen in the alloy may not be well defined. Although it is implied that a maximum solubility of oxygen in the alloy has been found, this reported solubility may also include the oxygen in the metal oxide which is soluble in the alloy as well as the oxygen solubility alone. It would be difficult if not impossible to calculate the free energy change due to the oxygen solubility in the alloy.

Free Energy Calculations for the Reaction of Beryllium with $\mathrm{Cm}_{2} \mathrm{O}_{3}$ Heat Source Product (E. E. Ketchen)

The thermodynamics of the reaction of $\mathrm{Cm}_{2} \mathrm{O}_{3}$ with beryllium to form $\mathrm{CmO}$ or curium metal have been investigated to evaluate the possibility of the reaction of $\mathrm{Cm}_{2} \mathrm{O}_{3}$ with beryllium metal. Since the $\mathrm{Cm}_{2} \mathrm{O}_{3}$ heat source product will contain some $\mathrm{PuO}_{2}$ at the time of fabrication, the reaction of beryllium with $\mathrm{PuO}_{2}$ was investigated. The $\mathrm{Cm}_{2} \mathrm{O}_{3}$ heat source material may be in contact with beryllium in the capsule.

The free energies of reaction of $\mathrm{Cm}_{2} \mathrm{O}_{3}$ with beryllium as noted in Eqs. 29 and 30 were reported previously. ${ }^{6}$ Table 14 shows that the formation of curium metal is favored but $\mathrm{CmO}$ should not be formed. As noted previously ${ }^{6}$ the reaction should not be too great since the $\mathrm{BeO}$ or $\mathrm{BeO} \cdot \mathrm{Cm}_{2} \mathrm{O}_{3}$ should form a protective coating over the beryllium up to the melting point.

The free energies for the reaction of $\mathrm{PuO}_{2}$ with beryllium (Eq. 31) were calculated and are shown in Table 14. Since the free energies are negative, it is evident that beryllium should react with the $\mathrm{PuO}_{2}$. However, as mentioned before the $\mathrm{BeO}$ and $\mathrm{BeO} \cdot \mathrm{Cm}_{2} \mathrm{O}_{3}$ compounds should form a protective coating over the metal to prevent further reaction. Since the melting point of beryllium is $1283^{\circ} \mathrm{C}$, the beryllium will be a liquid at $1300^{\circ} \mathrm{C}$ and probably would present more problems at this temperature.

$$
\begin{aligned}
\mathrm{Cm}_{2} \mathrm{O}_{3}(\mathrm{~s})+\mathrm{Be}(\mathrm{s}, l) & \rightarrow 2 \mathrm{CmO}(\mathrm{g})+\mathrm{BeO}(\mathrm{s}) \\
\mathrm{Cm}_{2} \mathrm{O}_{3}(\mathrm{~s})+3 \mathrm{Be}(\mathrm{s}, l) & \rightarrow 2 \mathrm{Cm}(\mathrm{s}, l)+3 \mathrm{BeO}(\mathrm{s}) \\
2 \mathrm{PuO}_{2}(\mathrm{~s})+\mathrm{Be}(\mathrm{s}, l) & \rightarrow \mathrm{Pu}_{2} \mathrm{O}_{3}(\mathrm{~s})+\mathrm{BeO}(\mathrm{s})
\end{aligned}
$$


Table 14. Gibbs Free Energy as a Function of Temperature

\begin{tabular}{cccr}
\hline Temperature & \multicolumn{4}{c}{$\Delta \mathrm{G}\left(\mathrm{kcal} / \mathrm{mole}\right.$ of $\mathrm{Cm}_{2} \mathrm{O}_{3}$ or $\left.\mathrm{PuO}_{2}\right)$} \\
\cline { 2 - 4 } $\mathrm{Eq} \cdot 29$ & $\mathrm{Eq} \cdot 30$ & $\mathrm{Eq} \cdot 31$ \\
\hline 600 & 143.98 & -14.89 & -21.68 \\
800 & 131.98 & -13.65 & -21.44 \\
1000 & 120.04 & -12.21 & -21.90 \\
1200 & 108.17 & -10.55 & -21.72 \\
1300 & 101.89 & -10.07 & -21.28 \\
\hline
\end{tabular}

Data Needed for Calculation of $\mathrm{Cm}_{2} \mathrm{O}_{3}$ Free Energy (E. E. Ketchen)

Experiments will be conducted soon to measure the specific heat $\left(C_{p}\right)$ of $\mathrm{Cm}_{2} \mathrm{O}_{3}$ as a function of temperature over the $400-1300^{\circ} \mathrm{C}$ range. Using these data and Eqs. 32 and 33 below, it should be possible to calculate the change in heat content and entropy for $\mathrm{Cm}_{2} \mathrm{O}_{3}$ over the $400-1300^{\circ} \mathrm{C}$ temperature range. It may be feasible to extrapolate the specific heat data to $298^{\circ} \mathrm{K}$, thus permitting calculation of $\mathrm{H}_{\mathrm{T}}-\mathrm{H}_{298^{\circ} \mathrm{K}}$ and $\mathrm{S}_{\mathrm{T}}-\mathrm{S}_{298^{\circ} \mathrm{K}}$. It should be noted that these two functions are for $\mathrm{Cm}_{2} \mathrm{O}_{3}$ and not for the formation of $\mathrm{Cm}_{2} \mathrm{O}_{3}$ from the elements.

$$
\begin{aligned}
& \mathrm{H}_{\mathrm{T}}-\mathrm{H}_{673^{\circ} \mathrm{K}}=\int_{673^{\circ} \mathrm{K}}^{\mathrm{T}} \mathrm{C}_{\mathrm{p}} \mathrm{dT} \\
& \mathrm{S}_{\mathrm{T}}-\mathrm{S}_{673^{\circ} \mathrm{K}}=\int_{673^{\circ} \mathrm{K}}^{\mathrm{T}}\left(\mathrm{C}_{\mathrm{p}} / \mathrm{T}\right) \mathrm{dT}
\end{aligned}
$$

From the heat content and entropy it is possible to calculate the free energy of $\mathrm{Cm}_{2} \mathrm{O}_{3}$ using $\mathrm{Eq} .34$ for temperatures up to $1300^{\circ} \mathrm{C}$.

$$
\mathrm{F}=\mathrm{H}-\mathrm{TS}
$$

Again, this free energy will be for $\mathrm{Cm}_{2} \mathrm{O}_{3}$, not the free energy of formation of $\mathrm{Cm}_{2} \mathrm{O}_{3}$. If the free energy of curium were known, it could be used, along with the known free energy of oxygen, to calculate the free energy of formation of $\mathrm{Cm}_{2} \mathrm{O}_{3}$. At present the experimental free energy functions $\left[\left(\mathrm{F}_{\mathrm{T}}-\mathrm{H}_{298^{\circ} \mathrm{K}}\right) / \mathrm{T}\right]$ are available for solid curium up to the melting point,

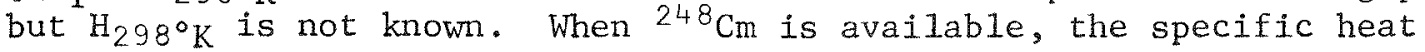
should be measured to as near $0^{\circ} \mathrm{K}$ as possible. These data could then be

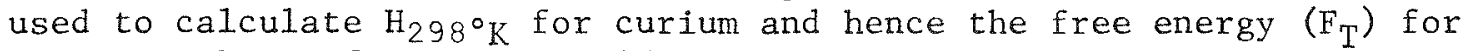
curium. This information would permit calculation of the free energy of formation for $\mathrm{Cm}_{2} \mathrm{O}_{3}$ over the desired range.

As data for the $\mathrm{C}_{\mathrm{p}}$ of $\mathrm{Cm}_{2} \mathrm{O}_{3}$ become available, estimates of the free energy of formation for $\mathrm{Cm}_{2} \mathrm{O}_{3}$ can be made which are probably better than the 
estimated values now used. In the event that $\mathrm{Cm}_{2} \mathrm{O}_{3}$ is shown to form only curium and oxygen, not Cmo, it may be possible to calculate the free energy function $\left[\left(\mathrm{F}_{\mathrm{T}}-\mathrm{H}_{298^{\circ} \mathrm{K}}\right) / \mathrm{T}\right]$ for $\mathrm{Cm}_{2} \mathrm{O}_{3}$. This function along with data now available would permit the calculation of the free energy function for the formation of $\mathrm{Cm}_{2} \mathrm{O}_{3}$ from its elements. The possibility of using this approach depends on the results of the vapor pressure/vapor species experiments now underway.

\section{Summary of Thermodynamic Calculation ( $E$. E. Ketchen)}

During the past few months several alloys which have potential use for $\mathrm{Cm}_{2} \mathrm{O}_{3}$ encapsulation have been investigated from a thermodynamic viewpoint considering possible reactions between the fuel and the alloy. In all cases a reference fuel consisting of $95 \% \mathrm{Cm}_{2} \mathrm{O}_{3}$ and $5 \% \mathrm{PuO}_{2}$ was assumed. The reactions considered were only those of the type

$$
\mathrm{F}_{\mathrm{x}} \mathrm{O}_{\mathrm{y}}+\mathrm{zM} \rightarrow \mathrm{M}_{\mathrm{z}} \mathrm{O} y+\mathrm{xF}
$$

where

$$
\begin{aligned}
\mathrm{F} & =\text { element in the fuel ( } \mathrm{Cm} \text { or } \mathrm{Pu}) \\
\mathrm{M} & =\text { constituent in alloy } \\
\mathrm{M}_{\mathrm{z}} \mathrm{O}_{\mathrm{y}} & =\text { most favorable oxide of } \mathrm{M}
\end{aligned}
$$

The calculations did not consider possible solubility effects or other compound formations. Free energy data for $\mathrm{Pu}_{2} \mathrm{O}_{3}$ were used as stand-ins for those of $\mathrm{Cm}_{2} \mathrm{O}_{3}$ which are not available. For the nine alloys investigated, no reactions of $\mathrm{Cm}_{2} \mathrm{O}_{3}$ (or $\mathrm{Pu}_{2} \mathrm{O}_{3}$ ) with any constituents were predicted. Calculations for three alloys also indicated no reactions with $\mathrm{PuO}_{2}$; two

\begin{tabular}{|c|c|}
\hline A110y & Constituent(s) Predicted to React With $\mathrm{PuO}_{2}$ \\
\hline Pt $-26 \% R h-8 \% W$ & None \\
\hline $\mathrm{Pt}-30 \% \mathrm{Rh}-8 \% \mathrm{~W}$ & None \\
\hline $\operatorname{Ir}-2 \% \mathrm{~W}$ & None \\
\hline Hafnalloy $20-20$ & Hf $(95.78$ atom $\%)$ \\
\hline $\mathrm{Ta}-10 \% \mathrm{~W}$ & Ta $(90.14$ atom $\%)$ \\
\hline Haynes 188 & $\mathrm{Si}(0.4$ atom $\%)$ and $\mathrm{La}\left(4 \times 10^{-5}\right.$ atom $\left.\%\right)$ \\
\hline Type 316 stainless steel & Si $(1.97$ atom \%) \\
\hline $\mathrm{T}-111$ & Hf $(2.03$ atom $\%)$ \\
\hline TZM & $\mathrm{Ti}(0.997$ atom $\%)$ and $\mathrm{Zr}\left(8 \times 10^{-4}\right.$ atom \% $)$ \\
\hline
\end{tabular}
indicated reactions of $\mathrm{PuO}_{2}$ with major constituents; and four indicated reactions of $\mathrm{PuO}_{2}$ with minor constituents. A summary of the $\mathrm{PuO}_{2} / \mathrm{alloy}$ calculations is shown below:

It should be noted that these calculations are limited in scope and that they are estimates at best. However, taken at face value, they seem to indicate that the plutonium oxides present in the fuel may influence the compatibility situation more than the curium oxide does. 


\section{$24{ }^{4} \mathrm{Cm}_{2} \mathrm{O}_{3}$ Property Characterization}

\section{Helium Release (P. Angelini)}

Three 0.46 -cm-diam by 0.14 -cm-thick ${ }^{244} \mathrm{Cm}_{2} \mathrm{O}_{3}$ pellets were hot-pressed using powder from batch SRL-31, and the residual carbon from the die body was removed by oxidation using the procedure which maintains the ${ }^{244} \mathrm{Cm}_{2} \mathrm{O}_{3}$ form. The pellets were then transferred, in an inert atmosphere container, to the balance glove box for mass and dimensional measurements.

The pellets were loaded into separate sample containers, and each container was placed in its respective furnace. The furnace temperatures were then increased to the predetermined values shown in Fig. 3 ; the initial heat-up helium release curves are shown in Fig. 4. In each case there was an extremely large amount of helium evolved during the initial evacuation of the sample tube. This helium, which could not be quantitatively measured, is probably that which is very close to the surface of the releasing unit or that which is held in open microcracks or grains.

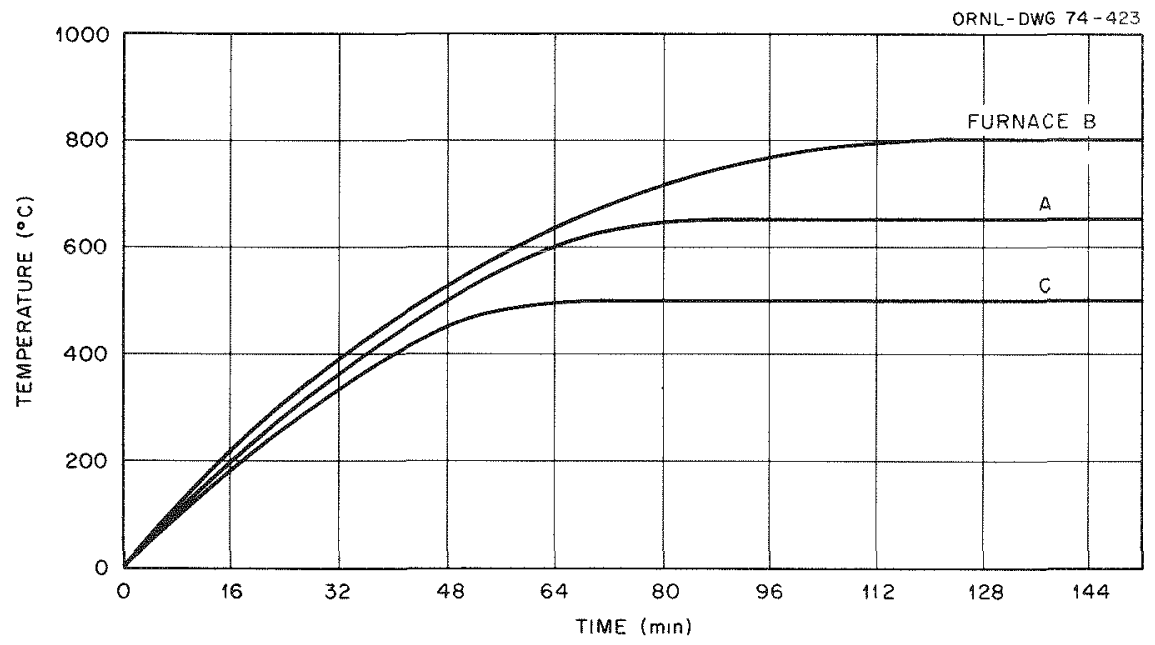

Fig. 3. Temperature Versus Time for Helium Release Tests.

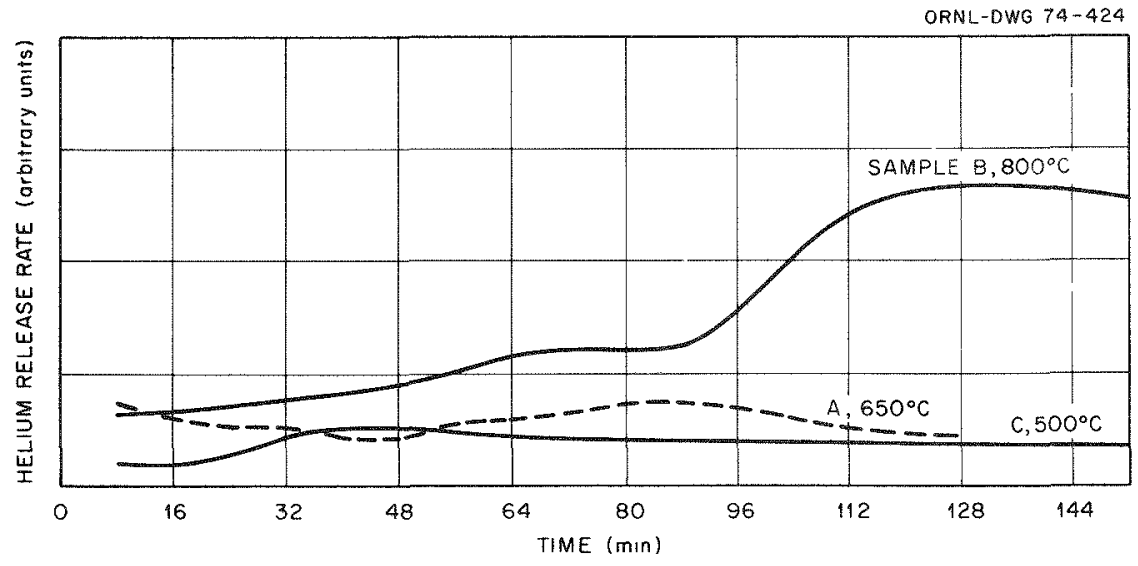

Fig. 4. Helium Release Rate Versus Time (0-152 hours). 
The release characteristics of samples $A$ and $C$ during their initial temperature increase were very similar. The release rate measured from sample $B$ was different; it increased to larger values above $750^{\circ} \mathrm{C}$ after decreasing from its first burst at a temperature. This second burst could be due to the annealing of radiation damage in the fuel. Thus, the microstructure of the fuel pellet maintained at $800^{\circ} \mathrm{C}$ could be very different from that of the pellets maintained at 500 or $650^{\circ} \mathrm{C}$. Also if this theory is true, the data reported previously in the helium release report on ${ }^{24}{ }^{4} \mathrm{Cm}_{2} \mathrm{O}_{3}$ could be extrapolated to a minimum temperature of $750^{\circ} \mathrm{C}$. Below this temperature another mechanism would predominate.

The plots of helium release rate versus time for samples $A\left(650^{\circ} \mathrm{C}\right)$, B $\left(800^{\circ} \mathrm{C}\right)$, and $\mathrm{C}\left(500^{\circ} \mathrm{C}\right)$ presented in $\mathrm{Fig} .5$ are based on experimental points which are average values of release rates. Individual points represent integrated release rates based on incremental measuring times ranging from 5 min to 3 days. Data are usually taken on a particular sample during a 1-day period every 3 days. During each incremental measuring time the release rate is recorded then integrated such that the amount of helium emitted over that incremental time is obtained. The abscissa of Fig. 5 represents the time from initial heating of the sample to the end of the incremental measuring time for the release rate.

The release rate curve for sample $A\left(650^{\circ} \mathrm{C}\right)$ was proceeding as expected up to $332 \mathrm{hr}$; during this period the burst-type helium emission was increasing. Beyond $332 \mathrm{hr}$ the burst-type helium emission increased tremendously. During the time period from 400 to $730 \mathrm{hr}$ the sample was emitting above its production rate. Thus, the inventory accumulated during the first $400 \mathrm{hr}$ at temperature was emitted during the 400 - to 730-hr period. Since the areas of the two regions are approximately equal, a very small helium inventory should remain in the sample. The data to be obtained after the $730-\mathrm{hr}$ period will show whether this phenomenon is cyclic or whether the release rate will level off, as expected, at the helium production rate for the sample. The sample will remain at this temperature for $\sim 500$ additional hours. If the helium release rate is equal to the production rate during this time the fuel pellet will be removed under inert atmosphere and observed. Part of the pellet will be sent for optical microscopy and another part studied by $x$-ray diffraction. The majority of the sample will be returned to the furnace, and the experiment continued for an additional $200 \mathrm{hr}$, after which the experiment will be terminated.

Sample $\mathrm{C}\left(500^{\circ} \mathrm{C}\right)$ has undergone the same phenomenon as sample $\mathrm{A}$; however, sample $B\left(800^{\circ} \mathrm{C}\right)$ has not undergone this phenomenon. Since the helium release rates for this sample have changed very little in $750 \mathrm{hr}$, equilibrium was probably reached in a short period. The experiment will be continued to prove this. Part of this pellet will also be studied by optical microscopy and $x$-ray diffraction analysis such that the differences between this pellet and sample A can be recorded. 
The release of stored helium at 500 and $650^{\circ} \mathrm{C}$ may be caused by alpha particles destroying the releasing units in the fuel. At these temperatures the damage caused by the alpha particles may be cumulative until the releasing unit can no longer accept any further damage and begins to be destroyed. The final helium inventory measurement at the completion of the long-term test should determine the amount of damage, and the studies by optical microscopy and by $x$-ray diffraction analysis should determine the type of damage which occurred. At a temperature of $800^{\circ} \mathrm{C}$, radiation damage is annealed to some equilibrium level and the releasing unit is not destroyed, and release by this mechanism does not occur.
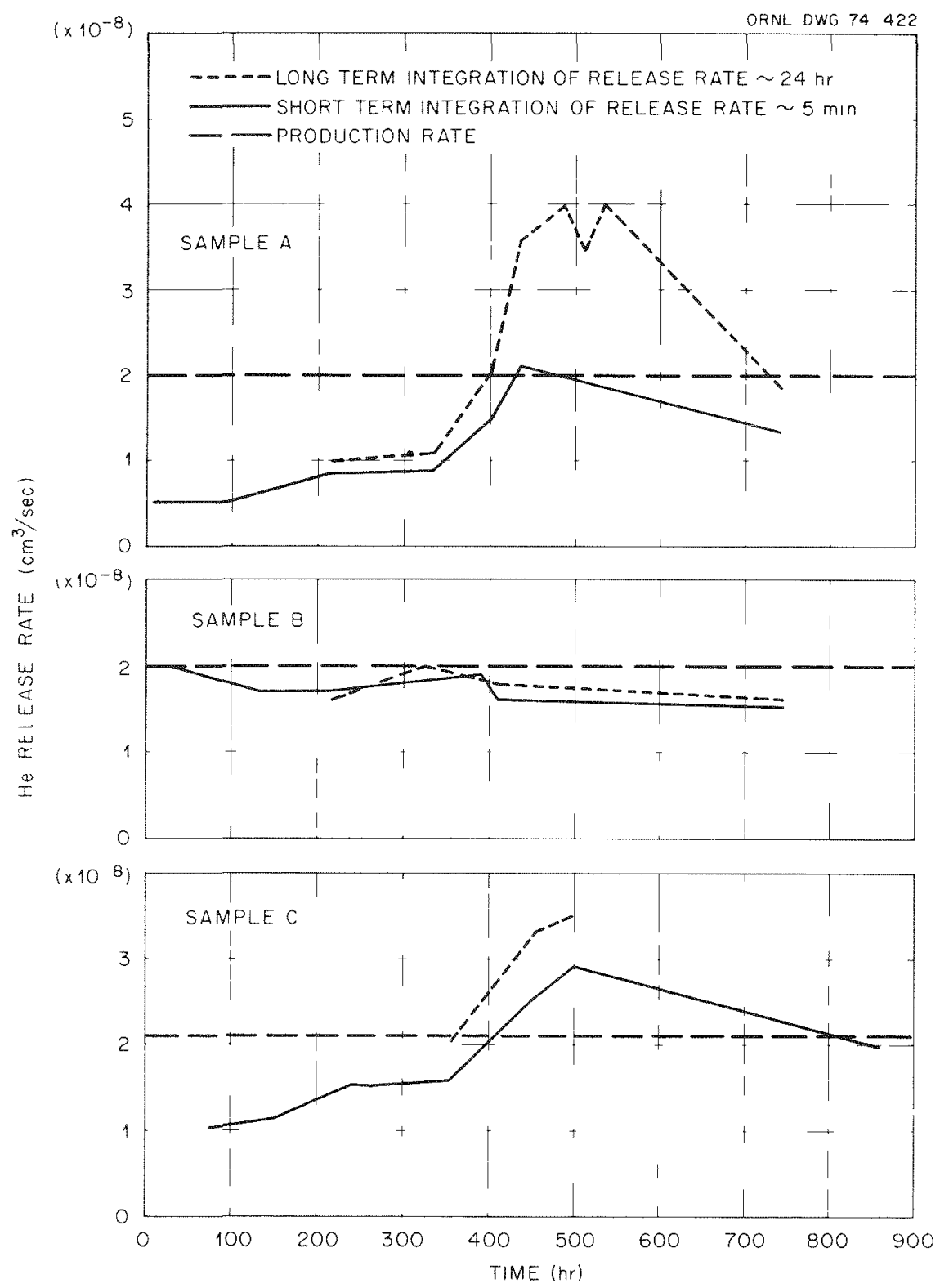

Fig. 5. Helium Release Rates Versus Time (0-900 hr). 
Vapor Pressure (P. Angezini and J. C. Posey)

The vapor pressure collection assembly was used in measuring the vapor pressure of curium metal. This provided a test to check both the unit and the range of agreement when an experiment was being performed on a radioactive element as reported in the literature. The equipment and procedure used by Smith et $a l^{7-8}$ in performing their experiments on ${ }^{244} \mathrm{Cm}$ metal were the same as those of Smith and Peterson ${ }^{8}$ in their experiments on ${ }^{244} \mathrm{Cm}_{2} \mathrm{O}_{3}$.

In our experiments a tungsten Knudsen cell was used. The temperature was measured by using a disappearing filament pyrometer. The black-body hole was located at the base of the Knudsen cell. The temperature values were corrected for pyrometer error, furnace window, and glove box window effects according to a calibration of the pyrometer and glass performed by the Standards Group of the Instrumentation and Control Division. The experiment was performed in the temperature range from 900 to $1600^{\circ} \mathrm{C}$. The vapor pressure collection assembly remained cool during the experiment. The rotary seal worked very well, the turning was smooth and could be performed easily. A technique for handling the platinum metal sample collection discs was worked out, and the radiation background was kept to a very minimum. The individual collection discs were counted with an alpha spectrometer by personnel in the Analytical Chemistry Division. The least square curve with corresponding standard error of coefficients for the vapor pressure of $2{ }^{44} \mathrm{Cm}$ metal is

$$
\log _{10} P=(3.834 \pm 0.411)-(17,939 \pm 641) / T
$$

where

$$
\begin{aligned}
& \mathrm{P}=\text { vapor pressure in atmospheres } \\
& \mathrm{T}=\text { absolute temperature in Kelvin }
\end{aligned}
$$

The vapor species is assumed to be ${ }^{244} \mathrm{Cm}$. The vapor pressure as reported above is lower than the vapor pressure obtained by Smith et $a I .{ }^{7}$ for the vapor pressure of curium. In the temperature region of $1100^{\circ} \mathrm{C}$ the difference could be explained by experimental temperature differences of $\sim 30^{\circ} \mathrm{C}$. Accurate temperature measurements and uniform Knudsen cell temperature are important factors in obtaining accurate vapor pressure data. The design of the furnace heat zone and Knudsen cell temperature measurement capability in our vapor pressure furnace is such that a minimum correction factor need be applied to the actual measurements.

Vapor pressure data are required for the prediction of the volatile migration of $\mathrm{Cm}_{2} \mathrm{O}_{3}$ in heat sources. Smith and Peterson ${ }^{8}$ have determined the vapor pressure of $\mathrm{Cm}_{2} \mathrm{O}_{3}$ in the range of $1570-2336^{\circ} \mathrm{C}$; however, current interest is in the range of about $800-1400^{\circ} \mathrm{C}$. The use of their data in the lower range involves a long extrapolation. Furthermore, the crystalline form of $\mathrm{Cm}_{2} \mathrm{O}_{3}$ changes at $1600^{\circ} \mathrm{C}$, which is at the lower edge of their range of measurement. The slope of the pressure-versus-temperature curve will be influenced to some degree by this transition. 
The Knudsen cell method will be used for the greater part of our measurements. Later, the Langmuir method will be used for the measurements at the lowest temperatures. This work is not a routine application of these methods of pressure measurement. The Knudsen cell method is used ordinarily at pressures down to $10^{-9}$ atm and the Langmuir method is used at pressures as low as $10^{-11} \mathrm{~atm}$. We hope to go to $10^{-14} \mathrm{~atm}$ at $1100^{\circ} \mathrm{C}$. Extrapolation of the data of Smith and Peterson ${ }^{8}$ indicates that below about $1100^{\circ} \mathrm{C}$ the pressure will be too low for determination.

The optical pyrometer system used for temperature measurement required calibration because the light used for measurement passes through two pieces of glass: the furnace window and the glove box window. The effect of the resulting light absorption on the pyrometer reading was measured by the Instrument Standards Group of ORNL using pieces of glass identical to the two windows. The pyrometer was also checked against a $\mathrm{Pt}-\mathrm{Pt}-10 \% \mathrm{Rh}$ thermocouple in the base of the Knudsen cell. The two groups of data were in good agreement. (The thermocouple vaporized during this work. It can be replaced if measurements below the optical pyrometer range are needed.)

In our application of the Knudsen cell method, the rate at which material leaves the orifice of the Knudsen cell is determined as follows: 1) Small stainless steel targets are mounted in a holder at the top of the vacuum furnace. The holder can be rotated to bring any one of ten targets over a hole leading into the furnace. 2) When in position, the target is struck by a known fraction of the total molecular beam of curium oxide leaving the Knudsen cell. 3) The amount of curium deposited on the targets is determined by an alpha-counting procedure.

It cannot be assumed with certainty that all molecules which strike the surface stick. In some similar reported cases, the condensation coefficient is much less than one. 9 , 10 (The condensation coefficient is the fraction of the molecules striking the surface which stick.) The size of the condensation coefficient is strongly influenced by the nature of the surface. High values occur when the condensing molecules readily fit into the crystalline lattice of the surface.

A series of targets with differing surfaces has been exposed in the vapor pressure apparatus. The surfaces were stainless steel, oxidized stainless steel, $\mathrm{Nd}_{2} \mathrm{O}_{3}$ deposited on stainless steel, lead oxide on stainless steel, and platinum. The curium deposits on these targets will be determined by alpha counting. A statistically significant variation in the observed rates of deposit will indicate the need of further investigation.

The problem of error because of accidental contamination of the targets is serious. The deposits on the targets are of the order of only $10^{-10} \mathrm{~g}$. Deposits of this size can be accurately measured by alpha counting, but an extremely small amount of contamination will cause a significant error. Furthermore, the targets are used in equipment which has been previously exposed to curium. 
The first targets exposed were leached by acid, and measurements were made of the total curium in the resulting solutions. The resulting data were badly scattered and were higher than expected. In two cases control targets which had not been exposed to the molecular beam showed greater curium deposits than any of the targets which had been exposed. The problem has been largely solved by counting the deposits while on the target and by the use of an appropriate masking procedure during the counting. Only the part of the surface which was exposed to the molecular beam is exposed during the counting. In one series of measurements with $\mathrm{Cm}_{2} \mathrm{O}_{3}$, six stainless steel targets were exposed at Knudsen cell temperatures which varied from 1202 to $1587^{\circ} \mathrm{C}$. These targets were counted using the mask. The logarithms of the vapor pressures calculated from these targets were plotted as a function of the reciprocal of the absolute temperature. An excellent straight line was obtained with five of the six points. The other point was high. The target on which this point was based showed appreciable contamination on the unexposed surfaces. It is likely that some contamination was also present on the exposed surface.

Numerical values will not be reported until questions of systematic error are resolved.

\section{$X$-Ray Diffraction (P. Angelini)}

The goniometer was realigned with the graphite crystal monochrometer in place. The monochrometer introduces a small loss in signal strength but increases the signal-to-noise ratio. After the final alignment procedure, scans of silicon and gold were obtained for use as standards under identical experimental settings for future experiments.

In October an x-ray diffraction scan was made on some pieces of a pellet which had been used in a seawater leach test, samples of which were scanned by $x$ ray in August, and stored in a seawater-filled container. The material was removed from the container, prepared on its mount under argon, and immediately inserted into the $x$-ray diffraction assembly. The system was evacuated and the scan was made. The original scan on this material had shown two patterns, a monoclinic pattern, probably $\mathrm{Cm}_{3} \mathrm{O}_{3}$, and a more intense fcc pattern with a cell parameter of $\bar{a}=5.369 \AA$. In the scan made after two month' storage in seawater, only an fcc pattern was seen; the calculated cell parameter was $a=5.391 \AA$. Also, the peaks were broader and less intense than had been the case in the first scan. Comparison of the two scans indicates that additional oxidation had occurred while the material was in storage in seawater, since the monoclinic pattern was not present in the second scan. The broader peaks in the second scan probably indicate additional radiation damage; and, the much larger fcc cell parameter of the second scan indicates that the sample had also hydrated.

A pellet which had been exposed to dry air for approximately four months was tranferred to the x-ray diffraction process glove box. The pellet was crushed and a scan of this sample was performed under an air atmosphere. Only an fcc pattern was obtained. The calculated lattice parameter was $a=5.377 \AA$. This lattice parameter is larger than the lattice parameter of freshly prepared and annealed $\mathrm{CmO}_{2}$ sample $(a=5.369 \AA)$. 
A monoclinic pattern was not observed. Thus the original $\mathrm{Cm}_{2} \mathrm{O}_{3}$ pellet had oxidized to $\mathrm{CmO}_{2}$ in the length of time that it had been exposed to air. The larger lattice parameter and broad peaks indicate radiation damage to the crystal structure.

Some of the remaining solid matter from the first boiling distilled water solubility experiment pellet was transferred to the $x$-ray diffraction system, and the sample was mounted under an argon atmosphere. The material seemed to be both in solution and in suspension in the distilled water. A scan was performed under vacuum immediately after the mount. was placed in the $x$-ray system. Two patterns were observed: a very strong fcc pattern and a strong hexagonal pattern. The fcc pattern had a calculated lattice parameter of $a=5.398 \AA$. The calculated lattict parameter of the hexagonal pattern was $a=6.396 \AA$ and $c=3.691 \AA$. The peaks were rather sharp and intense in both patterns. The fcc pattern is probably a hydrated form of $\mathrm{CmO}_{2}$ and the hexagonal pattern is attributed to $\mathrm{Cm}(\mathrm{OH})_{3}$. The lattice parameter for the hexagonal structure calculated from the data is very similar to the lattice parameter of various lanthanide hydroxides. Also the intensity and the number and position of the peaks reinforce the conclusion that the pattern was that of $\mathrm{Cm}(\mathrm{OH})_{3}$. This was the only sample of the leach test materials in which the hydroxide compound was identified.

Part of a pellet from the first set of pellets scheduled for use in the vapor pressure experiment was transferred to the $x$-ray diffraction process glove box (these fuel pellets were made from the purified curium oxide powder). A scan was performed over $22^{\circ}-85^{\circ} 2 \theta$, and the lines recorded showed the material to have two phases; both a monoclinic and an fcc structure were observed. The monoclinic structure was attributed to $\mathrm{Cm}_{2} \mathrm{O}_{3}$ monoclinic form and the fcc structure to a slightly reduced $\mathrm{CmO}_{2}$ form. Since the presence of $\mathrm{CmO}_{2}$ showed that some oxidation of the $\mathrm{Cm}_{2} \mathrm{O}_{3}$ had occurred, the pellets were rejected, and a second calcination/ pressing cycle using the purified material was made. A scan over $10^{\circ}-$ $85^{\circ} 2 \theta$ was performed on a sample soon after the calcining procedure. Very strong lines were present, all of which were attributed to the cubic $C$ form of $\mathrm{Cm}_{2} \mathrm{O}_{3}$. The material should be in the $\mathrm{C}$ form since the oxide had been taken to $1000^{\circ} \mathrm{C}$ in vacuum. Pellets were hot-pressed at $1450^{\circ} \mathrm{C}$ from the batch of calcined powder. A scan performed on one of the as-pressed pellets showed that the material had a monoclinic structure, with one line at $26.38^{\circ} 2 \theta$ attributable to graphite. Another pellet was processed through the carbon burn-off procedure; a scan of samples from this pellet showed that this sample also had a monoclinic form. There was one unaccounted for line at $20.86^{\circ} 2 \theta$; possibly some impurity oxidized during the carbon burn-off. The $26.38^{\circ} 2 \theta$ line was not detected, showing that carbon surface deposits had been burnt of the pellet. The lines of the scan on the pellet which had been through the carbon burn-off process were less intense than the lines of the scan on the as-pressed pellet. The monoclinic structures of both the pellets are attributable to the $B$ form of $\mathrm{Cm}_{2} \mathrm{O}_{3}$, which forms irreversibly at the hot-pressing temperature. The lower intensity of the lines in the scan of the pellet which had received the carbon burn-off treatment indicate a distortion of the crystal lattice relative to the as-pressed pellet. Both pellets were pressed at the same 
time, but the as-pressed pellet scan was made two days before the scan of the other pellet after the carbon removal procedure. The crystal distortion probably resulted from radiation damage, possibly influenced by helium effects rather than from the carbon burn-off process itself.

The results of these measurements indicate that the procedure used for pellet fabrication and carbon removal result in the desired fuel form. They also demonstrate the value of $x$-ray diffraction analysis as a tool for identification of structure; this is useful for proper description of processes occurring in various experiments. The $\mathrm{CmO}_{2}$ indicated by the scan of the material which was rejected probably resulted from some exposure to air during the post-pressing handling or transfer operations. This again points up the necessity of exclusion of oxygen in $\mathrm{Cm}_{2} \mathrm{O}_{3}$ handing operations.

\section{Emissivity (P. Angelini)}

The new furnace heat shields were fabricated and installed in the furnace which will be used for the emittance experiment. A graphite pellet was used for initial calibration experiments of the spectroradiometer. The new heat shield enabled the attainment of $1375^{\circ} \mathrm{C}$ as the maximum sample temperature at maximum furnace temperature.

The test of the spectroradiometer with its readout instruments demonstrated satisfactory operation of the unit. The mechanical chopping frequency was changed from 16 to $2.42 \mathrm{hz}$, and the lock-in amplifier was used in its tuned circuit mode. These two changes have greatly enhanced the signalto-noise ratio from the instrument. Excellent readings could be obtained from the system with sample temperatures from 700 to $1375^{\circ} \mathrm{C}$ and spectral range of $3.0,3.5,4.0,4.5,5.0$, and 5.5 microns in addition to the total radiation receiving mode.

Heat Capacity (E. ingelini)

The system has been checked. Final preparations are being made before the cell becomes radioactive.

Dimensional Stability (T. A. Butzer and C. L. Ottinger)

Observations of the three $25-W$ test pellets made in September continued. The two 25-W $\mathrm{Cm}_{2} \mathrm{O}_{3}$ pellets - one of purified $\mathrm{Cm}_{2} \mathrm{O}_{3}$ and the other of production-grade material - which had been stored under argon at $\sim 650^{\circ} \mathrm{C}$ were checked on November 20. The pellet of purified $\mathrm{Cm}_{2} \mathrm{O}_{3}$ (PCM-P2) was intact and no dimensional changes had occurred; this pellet was fabricated on September 18. Inspection of the pellet of production-grade $\mathrm{Cm}_{2} \mathrm{O}_{3}$ (batch $\mathrm{SRL}-31$ ) revealed that one large piece weighing $0.71 \mathrm{~g}$ and several small chips also totaling $0.71 \mathrm{~g}$ had broken off from one end of the pellet. This pellet was fabricated on September 27 and had last been inspected on october 30 , at which time it was still intact. The pellet 
of purified $\mathrm{Cm}_{2} \mathrm{O}_{3}$ ( $\mathrm{PCM}-\mathrm{P} 1$ ) which had been stored in air was also inspected; there was no significant change. During the two-month storage of PCM-P1 in dry air it lost a total of $10.7 \%$ of its original weight. Essentially all of this loss occurred during the first week, with the first observable loss occurring $70 \mathrm{hr}$ after the start of the air exposure. The loss was in the form of small chips flaking from the edges of the pellet ends. The body of the pellet has shown no evidence of swelling.

Based on the observations made on these three pellets, it would appear that ${ }^{244} \mathrm{Cm}_{2} \mathrm{O}_{3}$ pellets of this size can be stored at ambient temperature $\left(\sim 650^{\circ} \mathrm{C}\right.$ average surface temperature) in argon for several weeks without significant physical change. However, exposure to air should be prevented or held to a minimum to preclude deterioration of the pellet. The breakage of the SRI-3I pellet was probably caused by mechanical or thermal stress since the container in which it is stored has to be handled frequent $1 y$.

Behavior of Hot-Pressed $\mathrm{Cm}_{2} \mathrm{O}_{3}$ Pellet in Boiling Distilled Water (J. C. Posey)

A test was made of the effect of boiling distilled water on a hot-pressed $\mathrm{Cm}_{2} \mathrm{O}_{3}$ pellet containing 13.1 wt $\%$ of $248 \mathrm{PuO}_{2}$. The procedure was the same as that used with boiling seawater. The pellet was held in a basket of

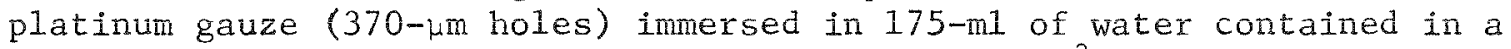
Pyrex glass flask. The pellet density was $7.8 \mathrm{~g} / \mathrm{cm}^{3}$ and its area was $0.561 \mathrm{~cm}^{2}$.

Samples of the water were taken in pairs from time to time and analyzed for $244 \mathrm{Cm}$. One sample was withdrawn through a sintered glass filter stick; the other was not filtered. At the end of the test the heat was turned off, boiling ceased, and all suspended material was allowed to settle for $24 \mathrm{hr}$. The water was again sampled.

After about $8 \mathrm{hr}$ the pellet started to disintegrate slowly. At first most of the material was present as large pieces which broke into progressively smaller and smaller pieces until at $144 \mathrm{hr}$ all of the material.

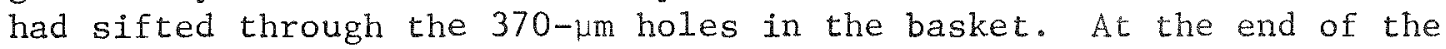
test, the $\mathrm{Cm}_{2} \mathrm{O}_{3}$ was present as a powder, partly on the bottom of the flask and partly suspended in the water.

The schedule of the disintegration of the pellet is given in Table 15. The concentrations of curium in the water illustrate the progressive break-up of the pellet. The curium concentrations in the unfiltered samples are dependent on the number of particles small enough to remain in suspension under the conditions of mild agitation as caused by the boiling water. The concentrations in the filtered samples are dependent on the number of particles capable of passing through the filter. The observation that both values increased with time indicates an increase in the amount of curium in the form of very small particles. 
Table 15. Disintegration of $\mathrm{Cm}_{2} \mathrm{O}_{3}$ Pellet in Boiling Distilled Water

\begin{tabular}{|c|c|c|c|}
\hline \multirow{2}{*}{$\begin{array}{l}\text { Time From } \\
\text { Beginning } \\
\text { Test (hr) }\end{array}$} & \multirow[t]{2}{*}{ Observations } & \multicolumn{2}{|c|}{$\begin{array}{c}{ }^{244} \mathrm{Cm} \text { Concentration } \\
(\mu \mathrm{g} / \mathrm{ml})\end{array}$} \\
\hline & & Filtered & Unfiltered \\
\hline 1 & Pellet intact; water clear & 0.037 & 0.060 \\
\hline 4 & Pellet intact; water clear & 0.044 & 0.076 \\
\hline 8.4 & $\begin{array}{l}\text { Pellet intact; one particle at } \\
\text { bottom of flask; water clear }\end{array}$ & - & - \\
\hline 24 & $\begin{array}{l}\text { Large irregular pieces in basket; many } \\
\text { particles at bottom of flask; water } \\
\text { clear }\end{array}$ & 0.24 & 1.2 \\
\hline 48 & Less materia1 in basket; water murky & 13 & 28 \\
\hline 76 & $\begin{array}{l}\text { One very small piece remaining in } \\
\text { basket; water very murky }\end{array}$ & 28 & 54 \\
\hline 144 & $\begin{array}{l}\text { No material in basket; water very } \\
\text { murky }\end{array}$ & 32 & 59 \\
\hline
\end{tabular}

The concentrations observed after $24 \mathrm{hr}$ settling at room temperature were $8.7 \mathrm{\mu g} / \mathrm{ml}$ for the filtered sample and $7.8 \mu \mathrm{g} / \mathrm{ml}$ for the unfiltered sample. These values are much lower than the final values for the boiling solution. The solution was clear at this time.

The disintegration of the pellet was expected. Similar disintegration had been observed with air-saturated distilled water at room temperature although a much longer time, 300-400 hr, passed before visible damage took place. ${ }^{6}$ Furthermore, Fullam and Roberts ${ }^{11}$ had observed a similar disintegration of pellets of $\mathrm{Nd}_{2} \mathrm{O}_{3}, \mathrm{Pm}_{2} \mathrm{O}_{3}$, and $\mathrm{Sm}_{2} \mathrm{O}_{3}$ in water. They showed that a hydration reaction occurred and that a hydrated oxide or hydroxide was produced. Because of the similarity of $\mathrm{Cm}_{2} \mathrm{O}_{3}$ to these oxides, it is likely that the reaction of $\mathrm{Cm}_{2} \mathrm{O}_{3}$ was the same. Free atmospheric oxygen is not present in boiling water, but some exposure to oxygen occurred afterward. In some of the powder examined using $x$-ray diffraction the presence of $\mathrm{Cm}(\mathrm{OH})_{3}$ and hydrated $\mathrm{CmO}_{2}$ were indicated. This work is described in greater detail in the "X-Ray Diffraction" section of this report.

To date, tests have been carried out using flowing air-saturated seawater and distilled water at room temperature and using boiling seawater and distilled water. All of these tests used $\mathrm{Cm}_{2} \mathrm{O}_{3}$ pellets of comparatively low density and high $240 \mathrm{Pu}$ content; tests with 10 w $240 \mathrm{Pu}$ content and higher density are planned. 
${ }^{244} \mathrm{Cm}_{2} \mathrm{O}_{3}$ Radiation Measurements (K. W. Haff)

The gamma spectrum of the $69.1-\mathrm{W}$ source was rechecked and the data evaluated. The source will be defueled early in 1974. A report on the radiation measurements from the source was drafted; the final report should be completed in January.

\section{Curium From Power Reactor Fuels (T. A. Butzer)}

The variations in isotopic composition of curium recovered from power reactor fuels was discussed in a previous report. ${ }^{1}$ Calculations and one set of experimental data indicated that significant increases in the abundance of the fissile nuclei, $243 \mathrm{Cm}$ and $245 \mathrm{Cm}$, can be anticipated relative to the product obtained from irradiation of plutonium targets in the Savannah River Plant reactors. Additional experimental evidence was found ${ }^{12}$ which supports the previous discussion. In this case, $\mathrm{UO}_{2}$ fuel rods were irradiated in the Vallecitos Boiling Water Reactor to $10 \mathrm{GWD} / \mathrm{MT}(\mathrm{U})$ and then transferred to the Dresden boiling water reactor for additional irradiation. Curium isotopic contents of full-cross-section fuel rod samples were measured by mass spectrometry. The data are given in Table 16 with values normalized to a decay period of five years after fuel discharge.

Table 16. Isotopic Abundance of Curium Recovered From Boiling Water Reactor Fuel

\begin{tabular}{ccccccc}
\hline $\begin{array}{c}\text { Sample } \\
\text { Number }\end{array}$ & $\begin{array}{c}{ }^{35} \mathrm{U} \text { Enrichment } \\
\text { (atom \%) }\end{array}$ & $\begin{array}{c}\text { Burnup } \\
\text { [GWD/MT (U)] }\end{array}$ & \multicolumn{3}{c}{ Isotopic Abundance (atom \%) } \\
\hline 68 & 3.53 & 28.5 & 2.27 & 92.96 & 4.26 & 0.52 \\
68 & 2.79 & 25.3 & 2.55 & 93.57 & 3.42 & 0.46 \\
70 & 2.79 & 25.3 & 2.28 & 93.53 & 3.76 & 0.43
\end{tabular}

The calculated production of ${ }^{244} \mathrm{Cm}$ in enriched-uranium-fueled PWR's as functions of burnup and $235 \mathrm{U}$ enrichment has been reported.1, 6 The calculated yields for a $3.3 \%{ }^{235} \mathrm{U}$ fuel enrichment given in Table 40 of reference 1 are in rather good agreement with measured datal3 of ${ }^{244} \mathrm{Cm}$ yields obtained from analyses of Yankee-Rowe reactor fuels. The YankeeRowe is a commercial PWR and the ${ }^{235} \mathrm{U}$ fuel enrichment was $3.4 \%$ for the Core I from which the ${ }^{244} \mathrm{Cm}$ yield data were obtained as a function of burnup. The two sets of data are shown in Fig. 6 .

The information obtained to date on the yield of curium isotopes and their isotopic abundances in power reactor fuels is summarized and interpreted, particularly with respect to the power density of ${ }^{244} \mathrm{Cm}_{2} \mathrm{O}_{3}$ fuels, in the following discussion. 
Few experimental data have been reported on the curium content of spent power reactor fuels and even less on the isotopic abundances. However, the available data are in sufficiently close agreement with calculated values derived from assumed average operating conditions of reference reactor types to allow predictions by calculations to be made with reasonable confidence. Reference reactor models include the light-water moderated reactor (LWR), high-temperature, gas-cooled graphite moderated reactor (HTGR), and liquid-metal-cooled fast breeder reactor (LMFBR). The LWRs are of two types: the boiling water reactor (BWR) and pressurized water reactor (PWR).

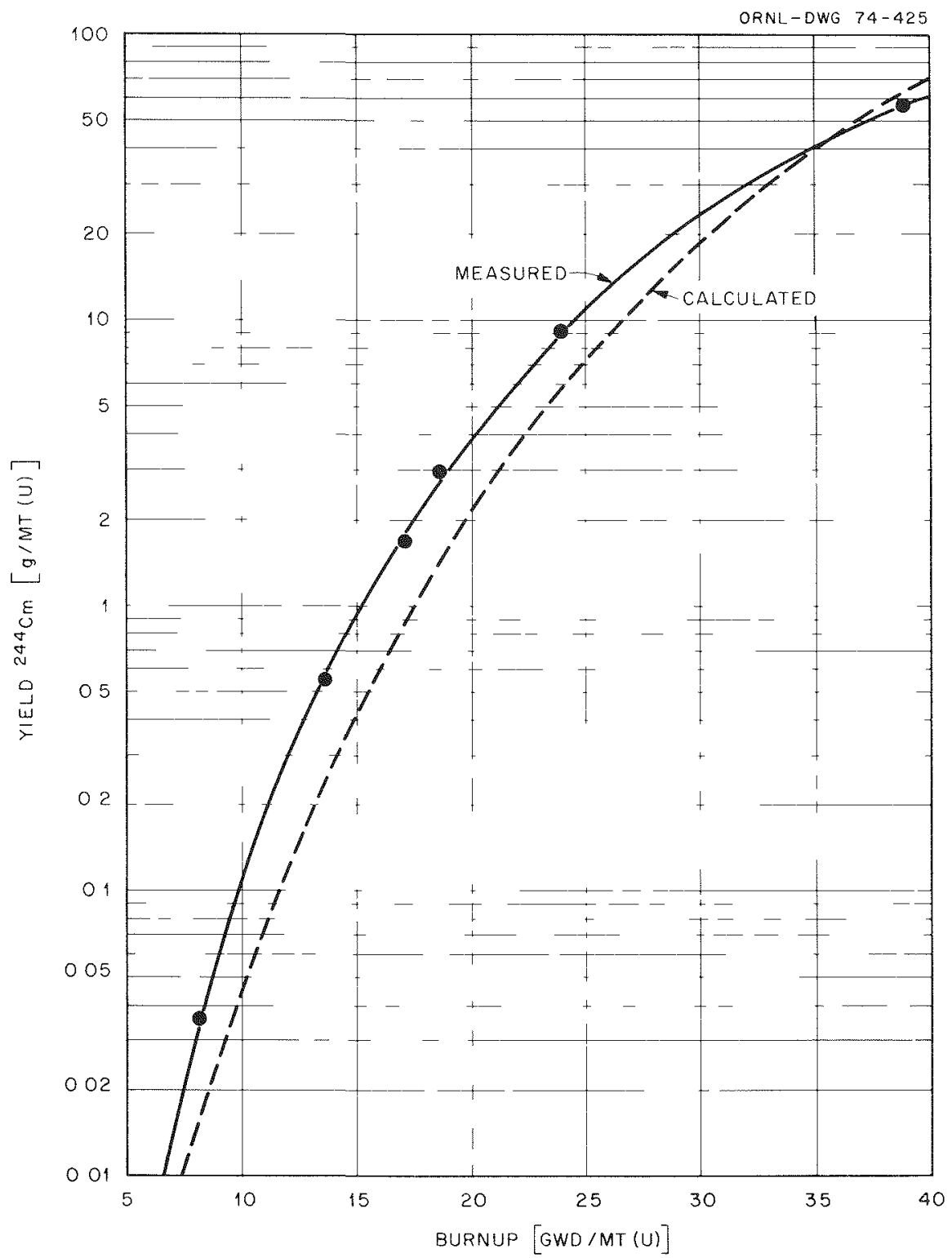

Fig. 6. Comparison of Calculated and Measured Yield of $2{ }^{44} \mathrm{Cm}$ in Enriched-Uranium-Fueled PWR. 
A projection of the growth of the nuclear power industry in the United States 14 indicates that the LWRs will predominate at least through 1985; therefore, the power density of ${ }^{244} \mathrm{Cm}_{2} \mathrm{O}_{3}$ fuels available from reprocessing of these reactor fuels is of most practical interest. The characteristics of curium recovered from BWR fuel are expected to closely approximate those from PWR fuel based on equal burnup of ${ }^{235} \mathrm{U}$-enriched uranium and are not considered separately. However, beginning about the end of this decade, some of the PWRs are expected to be fueled with recycled plutonium. The effect of plutonium recycle is to increase the yield (about 50 fold) of curium and to reduce the abundance of the ${ }^{244} \mathrm{~cm}$ isotope.

Predictions of the isotopic composition of ${ }^{244} \mathrm{Cm}_{2} \mathrm{O}_{3}$ fuels obtained from commercial reprocessing of fuels from various power reactors are speculative at this time. Several factors contribute to the uncertainty. It is assumed that high-level waste streams which contain the curium fraction will be accumulated as solutions in common waste storage tanks for periods of three to six years before curium recovery operations begin. Thus, curium originating in reactor fuels of differing composition, reactor flux spectra, and burnup will have an opportunity to homogenize during storage and average the differences in isotopic composition. The recent trend toward standardization of reactor designs in a mature nuclear power industry will make future predictions of curium isotopic composition more certain.

Using the predicted nuclear power growth, 14 it can be assumed that the majority of reactor fuels for reprocessing will derive from PWRs fueled with enriched uranium, with gradually increasing numbers being fueled by plutonium recycle. It is further assumed that chemical recovery and purification of curium will be done after a decay period of four years to reduce the ${ }^{242} \mathrm{Cm}$ to negligible amounts, and that ${ }^{244} \mathrm{Cm}_{2} \mathrm{O}_{3}$ fuels will be fabricated one year after the chemical recovery. Chemical processing removes essentially all of the plutonium residual and decay product but leaves an estimated maximum 3 wt $\%$ of other contaminants.

The isotopic composition of curium in enriched-uranium PWR fuels varies somewhat depending on the amount of $235 \mathrm{U}$ enrichment and the burnup leve 1 attained. During power reactor start-up periods, lasting for two to three years, portions of the reactor cores are discharged with relatively low burnup values. The calculated effects of ${ }^{235} \mathrm{U}$ enrichment and burnup are shown in Tables 17 and 18 .

Table 17. Influence of $235 \mathrm{U}$ Enrichment on Isotopic Abundance of $244 \mathrm{Cm}$ at $33 \mathrm{GWD} / \mathrm{MTU}$ and Four-Year Decay Period

\begin{tabular}{cc}
$\begin{array}{c}\text { Enrichment } \\
\text { (Weight \%) }\end{array}$ & $\begin{array}{c}\text { Isotopic Abundance of }{ }^{244} \mathrm{Cm} \\
\text { (Weight \%) }\end{array}$ \\
\hline 1.5 & 89.76 \\
2.5 & 91.09 \\
3.3 & 92.08 \\
\hline
\end{tabular}


Table 18. Influence of Burnup on Isotopic Abundance of ${ }^{244} \mathrm{Cm}$ at $3.3 \% 235 \mathrm{U}$ Reactor Fuel Enrichment and Four-Year Decay Period

\begin{tabular}{cc}
\hline Burnup (GWD/MTU) & $\begin{array}{c}\text { Isotopic Abundance of }{ }^{244} \mathrm{Cm} \\
\text { (Weight \%) }\end{array}$ \\
\hline 3.3 & 98.18 \\
16.5 & 95.41 \\
33.0 & 92.08 \\
\hline
\end{tabular}

The information in Tables 17 and 18 shows that the ${ }^{244} \mathrm{Cm}$ content of the curium fraction increases with increased enrichment of the reactor fuel and decreases with increased burnup. These two effects tend to be compensating if it is assumed that waste streams from the reprocessing of a variety of reactor fuels are mixed in aqueous waste storage tanks. Most PWRs are expected to be fueled with $\sim 3 \% 235 \mathrm{U}$ enriched uranium, 14 therefore, it is recommended that 92.08 wt \% isotopic abundance of $244 \mathrm{~cm}$ at a four-year decay period be used as a most probable value. The corresponding value for a PWR fueled with recycled plutonium and burnup of $33 \mathrm{GWD} / \mathrm{MTU}$ is 86.92 wt $\%{ }^{244} \mathrm{Cm}$ at the four-year decay period.

In calculation of the probable power density of ${ }^{244} \mathrm{Cm}_{2} \mathrm{O}_{3}$ fuels obtained from power reactor operations, previous assumptions must be borne in mind: the ${ }^{242} \mathrm{Cm}$ content of the curium fraction is decayed to negligible amounts, 3 wt \% of impurity oxides are present in the fuel but plutonium has been removed at the end of a four-year decay period, fuel form fabrication is done one year after chemical recovery, the other principal isotopes of curium $\left(2{ }^{4} \mathrm{Cm}, 2{ }^{2} \mathrm{Cm}\right.$, and $\left.{ }^{246} \mathrm{Cm}\right)$ do not contribute significantly to the power of the fuel, and fuel density of $10.3 \mathrm{~g} / \mathrm{cm}^{3}$ is attainable in hot-pressed pellets. The specific power of the ${ }^{244} \mathrm{Cm}_{2} \mathrm{O}_{3}$ fuel will decrease by $3.74 \%$ during the holding period of one year between chemical processing and fuel fabrication due to decay of ${ }^{244} \mathrm{Cm}$ to ${ }^{240} \mathrm{Pu}$. Mass loss due to the escape of helium is negligible in this length of time. The power density of the two sources of $2{ }^{44} \mathrm{Cm}_{2} \mathrm{O}_{3}$ isotopic power fuels is summarized in Table 19.

Table 19. Power Density of ${ }^{244} \mathrm{Cm}_{2} \mathrm{O}_{3}$ Fue1 Forms

\begin{tabular}{lcc}
$\begin{array}{l}\text { Source of } \\
\text { Curium-244 }\end{array}$ & $\begin{array}{c}\text { Specific Power } \\
(\mathrm{W} / \mathrm{g})^{\mathrm{a}}\end{array}$ & $\begin{array}{c}\text { Power Density } \\
\left(\mathrm{W} / \mathrm{cm}^{3}\right)^{\mathrm{a}}\end{array}$ \\
\hline PWR, $235 \mathrm{U}$ enriched & 2.215 & 22.8 \\
PWR, Pu recycle & 2.09 & 21.5 \\
\hline $\begin{array}{l}\text { at five-year decay after discharge of the } \\
\text { reactor fuel, density of } 10.3 \mathrm{~g} / \mathrm{cm}^{3} \text {. }\end{array}$
\end{tabular}


The calculations given in Table 19 indicate that ${ }^{244} \mathrm{Cm}_{2} \mathrm{O}_{3}$ fuels used for heat sources about 1980 should approximate fuel power densities of $22.8 \mathrm{~W} / \mathrm{cm}^{3}$ and decrease to a probable limit of $21.5 \mathrm{~W} / \mathrm{cm}^{3}$ around 1990 as plutonium recycle fuels for the PWR come into greater use.

Criticality of ${ }^{244} \mathrm{Cm}_{2} \mathrm{O}_{3}$ Fuels (T. A. Butzer)

Criticality of the actinide elements has been reviewed by clayton and Bierman. 15 of the curium nuclei which are present in power reactor fuels, those containing an odd number of neutrons, ${ }^{243} \mathrm{Cm}, 245 \mathrm{Cm}$, and $2{ }^{7} \mathrm{Cm}$, are classified as fissile and those containing an even number of neutrons, ${ }^{244} \mathrm{~cm},{ }^{246} \mathrm{~cm}$, and ${ }^{248} \mathrm{Cm}$, are classified as fissionable. Fissionable nuclei are those for which a chain reaction is possible with most of the fissions caused by high-energy neutrons. Fissile nuclei are those for which a chain reaction is possible with the fissions caused by slow, or thermal, neutrons. The only data on critical experiments with curium nuclei is a material-replacement experiment with ${ }^{244} \mathrm{Cm}$ reported by Barton. 16 He estimated that the critical mass of a bare metal sphere of $244 \mathrm{~cm}$ (density $13.5 \mathrm{~g} / \mathrm{cm}^{3}$ ) is $27.7 \pm 2.5 \mathrm{~kg}$. Clayton and Bierman 15 calculated the critical mass of a similar sphere of $244 \mathrm{Cm}$ to be $23.2 \mathrm{~kg}$.

Preliminary calculations of the criticality of four representative heat source systems indicate that there should be no problem with these systems

even if the ${ }^{244} \mathrm{Cm}_{2} \mathrm{O}_{3}$ contains $12 \%$ of the fissile isotopes ${ }^{243} \mathrm{Cm}$ plus ${ }^{245} \mathrm{Cm}$. The study will be completed in January 1974 and a detailed report made.

\section{REFERENCES}

1. Eugene Lamb, ORNL Isotopic Power Euels Quarterly Report for Period Ending September 30, 1973, ORNL-4932, Oak Ridge National Laboratory.

2. Alvin Glassner, The Thermochemical Properties of the Oxides, Fluorides and Chlorides to $2500^{\circ} \mathrm{K}$, ANL-5750, Argonne National Laboratory (1957).

3. F. L. Oetting, "The Chemical Thermodynamic Properties of Plutonium Compounds," Chem. Rev. 67, 261-97 (June 1967).

4. R. A. Kent, Thermodynamic AnaZyses of MHW Space Electric Power Generator, LA-5202MS, Los Alamos Scientific Laboratory (March 1973).

5. S. Stecura, Observation of Oxide Particles Below the Apparent Oxygen Solubility Limit in Tantalum, NASA TMX-2889, Lewis Research Center (September 1973).

6. Eugene Lamb, ORNL Isotopic Power Fuels Quarterly Report for Period Ending June 30, 1973, ORNL-4917, Oak Ridge National Laboratory. 
7. P. K. Smith, W. H. Hale, and M. C. Thompson, "Vapor Pressure and Crystal Structure of Curium Metal," $J$. of Chem. Physics 30, 506676 (1969).

8. P. K. Smith and D. E. Peterson, "High-Temperature Evaporation and Thermodynamic Properties of $\mathrm{Cm}_{2} \mathrm{O}_{3}, " \mathrm{~J}$. Chem. Phys. 52(10), 496372 (May 1970).

9. John L. Margrave, Physiochemical Measurements at High Temperatures, J. O'M. Bockris, J. L. White, and J. D. McKenzie (eds.), Butterworths Scientific Publications, London, 1959, pp. 230-31.

10. Saul Dushman and J. M. Lafferty, Scientific Foundations of Vacum Technique, 2nd Ed., John Wiley \& Sons, Inc., New York, 1962, pp. 408-10.

11. H. T. Fullman and F. P. Roberts, Reactions of the Sesquioxides of Pm, Nd, and Sm With Water, BNWL-1421, Pacific Northwest Laboratories (June 1970).

12. F.H. Megerth, Compiler, Zircaloy-Clad UO 2 Fuel Rod Evaluation Program Quarterly Progress Report No. 9, GEAP-10160, General Electric Company (February 1970).

13. R. P. Matsen, An Analysis of Yankee-Rowe Bumup Data, BNwL-1122, Pacific Northwest Laboratory (July 1969).

14. The Growth of Nuclear Power 1972-1985, WASH-1139 (Rev. 1), December 1971.

15. E. D. Clayton and S. R. Bierman, "Criticality Problems of Actinide Elements," Actinides Reviews I, 409-32 (1971).

16. D. M. Barton, "Central Reactivity Contributions of ${ }^{244} \mathrm{Cm},{ }^{239} \mathrm{Pu}$, and $235 \mathrm{U}$ in a Bare Critical Assembly of Plutonium Metal," Nucl. Sci. Eng. 33, 51 (1968). 
ORNL -4939

UC-33 - Nuclear Propulsion

Systems and Aerospace Safety

INTERNAL DISTRIBUTION

1-3. Central Research Library
4. ORNL - Y-12 Technical Library
Document Reference Section
5-24. Laboratory Records Department
25. Laboratory Records, ORNL RC
26. G. M. Adamson, Jr.
27. P. Angelini
28. N. C. Bradley
29. T. A. Butler
30. C. E. Clifford
31. F. L. Culler
32. J. E. Cinningham
33. J. R. DiStefano
34. R. G. Donnelly
35. D. E. Ferguson
36. J. H. Gillette
37. K. W. Haff

38. R. F. Hibbs

39. M. R. Hi11

40. H. Inouye

41. E. Lamb

42. R. E. Leuze

43. H. C. McCurdy

44. C. L. Ottinger

45. Herman Postma

46. J. C. Posey

47. A. F. Rupp

48. R. W. Schaich

49. M. K. Skinner

50. D. A. Sundberg

51. D. B. Trauger

52. J.R. Weir

53. A. Zucker

\section{EXTERNAL DISTRIBUTION}

54. R. D. Baker, Los Alamos Scientific Laboratory

55. F. P. Baranowski, Division of Production \& Materials Management, AEC

56. M. Bell, TRW Systems

57. Linda Benker, Thermo Electron Corporation

58. R. F. Borlick, Division of Production \& Materials Management, AEC

59. H. C. Carney, Jr., Gulf Energy and Environmental Services

60. R. T. Carpenter, Division of Space Nuclear Systems, AEC

61. W. T. Cave, Mound Laboratory

62. Commander, Naval Undersea Research and Development Center

63. G. R. Crane, Headquarters AFSC (XRTS), Andrews Air Force Base

64. G. P. Dix, Division of Space Nuclear Systems, AEC

65. R. English, NASA, Lewis Research Center

66. T. P. Fleming, Naval Facilities Engineering Command

67. R. K. Flitcraft, Mound Laboratory

68-70. E. E. Fowler, Division of Applied Technology, AEC

71. L. Frank, Weiner Associates, Inc.

72. A. G. Fremling, AEC-Richland Operations office

73. D. S. Gabrie1, Division of Space Nuclear Systems, AEC

74. N. Goldenberg, Division of Space Nuclear Systems, AEC

75. M. Goldman, Division of Biomedical \& Environmental Research, AEC

76. R. C. Hamilton, IDA - Room 19, 400 Army-Navy Drive, Arlington, VA

77. W. J. Haubach, Division of Physical Research, AEC

78. M. G. Hegarty, Radio Corporation of America

79. T. B. Hindman, AEC-Savannah River Operations Office 
80. R. E. Hopkins, U.S. Army Mobility Equipment R\&D Center

81. Ian Jones, TRW Systems

82. R. J. Katucki, General Electric

83. T. B. Kerr, NASA Headquarters

84. F. E. Kruesi, Savannah River Laboratory

85. G. Linkous, Teledyne-Isotopes, Inc.

86. W. A. McDonald, Teledyne-Isotopes, Inc.

87. T. A. Nemzek, Division of Reactor Research and Development, AEC

88. G. A. Newby, Division of Space Nuclear Systems, AEC

89. W. G. Parker, Westinghouse Astronuclear Laboratory

90. F. K. Pittman, Division of Waste Management \& Transportation, AEC

91. G. B. Pleat, Division of Production \& Materials Management, AEC

92. R. W. Ramsey, Jr., Division of Waste Management \& Transportation, AEC

93. P. K. Smith, E. I. duPont-Savannah River Laboratory

94. J. M. Teem, Division of Physical Research, AEC

95. H. H. Van Tuyl, Pacific Northwest Laboratories

96. R. L. Wainwright, Dayton Area Office, AEC

97. J. L. Womack, E. I. duPont-Savannah River Plant

98. AEC, Richland Operations office

99. AEC, Savannah River Operations office

100. General Electric Company, MSD, AEC

101. General Electric Company, VNC, AEC

102. NASA, Goddard Space Flight Center

103. NASA, Langley Research Center

104. NASA, Manned Spacecraft Center

105. NASA, Marshall Space F1ight Center

106. Navy Space Systems Activity

107. Teledyne-Isotopes, Inc., Timonium, MD

108. Research and Technical Support Division, AEC, ORO

109. Patent Office, AEC, ORO

110-276. Given Distribution as Shown in TID-4500 Under Nuclear Propulsion

Systems and Aerospace Safety Category (25 copies - NTIS) 